UDK:339.13

Izvorni znanstveni rad

Primljen: 27. ožujka 2018.

Prihvaćen: 2. lipnja 2018.

Dr. sc. Tin MATIĆ,

odvjetnik, Zagreb

tin.matic@zg.t-com.hr

\title{
ELEKTRONIČKI AGENT
}

Sažetak: U radu se daje prikaz regulacije elektroničkog agenta kao jednog od čistih oblika elektroničke komunikacije - načina za sklapanje ugovora elektroničkim putem. S obzirom na nepostojanje regulacije elektroničkog agenta u Europi te Bosni i Hercegovini i Hrvatskoj, autor daje prikaz regulative SAD-a kao paradigmatičnog pravnog izvora. Analizira se razlika u shvaćanjima propisa SAD-a i kontinentalnih prava oko očitovanja volje, odnosno analizira razlika između očitovanja volje i manifestacije volje te njihov utjecaj na sklapanje ugovora putem elektroničkog agenta. Razmatra se postajanje te način iskazivanja volje pri sklapanju ugovora putem elektroničkog egenta, kao i potreba za objektivnim tumačenjem volje, odnosno manifestacije volje koju iskazuje elektronički agent, a za osobu za čije ime i za čiji račun nastupa u pravnom prometu. Također se razmatra regulativa ovog područja u sklopu nacionaolnog Zakona o obveznim odnosima. Sugerira se minimalni pravni zahvat u nacionalnu regulativu kako bi se osigurala pravna sigurnost korištenja elektroničkog agenta u praksi.

Ključne riječi: elektronički agent, sklapanje ugovora, očitovanje volje, manifestacija volje, UETA (Jednoobrazni zakon za elektroničke transakcije), UCITA (Jednoobrazni zakon za računalne informatičke transakcije, E-sign Act SAD-a (Zakon o elektroničkim potpisima u globalnoj i nacionalnoj trgovini $S A D-a)$.

\section{Uvod}

Elektronički agenti mogli bi se, s funkcionalne strane, lakonski definirati kao tehnologija koja će olakšati trgovanje na e-tržištima smanjujući transakcijske troškove i trajanje 
same transakcije. ${ }^{1} \mathrm{U}$ tehničkom ili informatičkom ${ }^{2}$ smislu radi se o komadiću softvera koji obavlja određene zadatke za korisnika. ${ }^{3} \mathrm{U}$ pravnom jeziku, termin ,agent“ pretpostavlja primjenu pravnih normi važećih za agenta i principala. Agent u pravilu znači posrednik ili zastupnik te bi sukladno tome bio podređen regulaciji ugovora o posredovanju ili zastupanja iz Zakona o obveznim odnosima. $U$ informatici ${ }^{4}$ se elektroničkim agentom naziva programski agent (software agent) i definira se kao program, koji djeluje u ime svojeg vlasnika ili korisnika, obavljajući složene informacijske i komunikacijske poslove u mreži

Općenito je u današnje vrijeme prepoznata valjanost ugovora sklopljenih putem elektroničkih agenata. No, unatoč tome, postoje određena problematična područja pravne regulacije. Kako je u svijetu uobičajeni termin electronic agent, on se koristi i u doslovnom hrvatskom prijevodu iz jednostavnog razloga - kako bi se prepoznalo o čemu se govori. Bez obzira na to, postoji puna svijest o pogrešnosti tog naziva za predmet proučavanja i unutar hrvatskog i unutar engleskog jezičnog područja, ali i svih pravnih područja, s obzirom na to da se ne radi o zastupanju ili posredovanju u smislu tradicionalnih pravnih shvaćanja i definiranja trgovačkog i građanskog prava.

Agent je osoba koja poduzima radnje za ili umjesto druge osobe na temelju ovlaštenja te druge osobe. U hrvatskom pravnom nazivlju ovaj termin prevodimo sa „zastupnik“ pa bi odgovarajući hrvatski termin bio ,elektronički zastupnik.“ No, s obzirom na to da u svjetskim razmjerima sustavi common lawa, a tako i civil law sustava koriste termin elektronički agent nema razloga da se taj termin ne koristi i unutar hrvatskog pravnog nazivlja. Za isti se pojam koristi i termin

\footnotetext{
${ }^{1}$ Tako i Petrić, A.: Agentski temeljeno elektroničko poslovanje, dostupno na https://bib.irb.hr/datoteka/332127.Petric_Ana_-_Agentski_temeljeno_elektronicko_poslovanje.pdf, str. 1.-10., str. 1. (14.4.2018.) (nema naznake časopisa objave).

${ }^{2}$ Informatika se određuje kao znanstvena disciplina koja se bavi proučavanjem, razvojem i uporabom postupaka i sredstava za (automatsku) obradu podataka - prema Galešev, V. et al: Informatika i računalstvo, Sysprint, Zagreb, 2009., str. 7.

${ }^{3}$ Tako Bagić Babac, M: Programski agenti, Infotrend br. 9, Zagreb. 2009., str. 48. - 49., str. 48. dostupno i na www.infotrend.hr/clanak/2009/10/programski-agenti.45.838.html, (14.4.2018.).

${ }^{4} \mathrm{O}$ ulozi i značenju informatike u pravu vidjeti Šimundić, S.: Pravna informatika, Pravni fakultet u Splitu, Split, 2007., str. 23-60.
} 
inteligentni agent ${ }^{5}$ ili prodajni agent (shopping agent) ${ }^{6}$, ili umjetni agent (artificial agent), ${ }^{7}$ kao i „,roboti“ ili „,botovi““ (,robots“, ,,bots“ ili „,knowbots“, ,softbots“ ili ,taskbots ${ }^{\text {“ }}$ ), samostalni agenti ili drugi inteligentni agenti. ${ }^{8}$

\section{Pravna koncepcija elektroničkog agenta}

Ako pretpostavimo da su svi roboti, odnosno elektronički agenti nužno softver, znači li to da je svaka softverska aplikacija potencijalno elektronički agent? Naravno da ne. Ovisno o osnovnim svojstvima koja imaju elektronički agenti kao softverski programi može se razlikovati njihova razina, od najjednostavnijih do složenijih. Dakle, da bi se uopće mogao okarakterizirati kao agent, softver mora posjedovati neka osnovna obilježja u nekoj autonomnoj razini, ali nužno mora poduzimati neku pravno relevantnu radnju. U pravilu je to questio facti i teško je iz pravne perspektive postaviti neko objektivno pravilo kada softver prelazi u elektroničkog agenta, no vjerojatno bi to bilo puno jednostavnije informatički izraziti.

Zbog određenja minimalne pravne regulacije elektroničkog agenta, nužno je posegnuti za pravima koja barem u osnovi reguliraju takav elektronički način sklapanja ugovora kako bi se shvatila njihova pravna priroda te pravna definicija, odnosno sadržaj i određenje. Pri tome se misli prvenstveno na pravo SAD-a. Naime, UNCITRAL-ov Model zakon o elektroničkoj trgovini ${ }^{9}$ ne sadrži izričito ovakve odredbe te je uzor ovoj regulaciji Jednoobrazni zakon za elektroničke transakcije. ${ }^{10}$

\footnotetext{
${ }^{5}$ Tako Bayamloglu, E.: Intelligent Agents and Their Legal Status, Ankarabarreview, br. 2008/1, Ankara, str. 46.54, str. 53.-54., dostupno na htt://www.ankarabarosu.org.tr/siteler/AnkaraBarReview/tekmakale/2008-1/8.pdf, (4.2.2014.).

${ }^{6}$ Tako van Haentjens, O., University of Stocholm, Shopping Agents and Their Legal Implications Regarding Austrian Law, dostupno na

http://citeseerx.ist.psu.edu/viewdoc/download?doi=10.1.1.201.9341\&rep=rep1\&type=pdf, (4.2.2015.) - nema naznake časopisa izdanja, kao niti broja stranica.

${ }^{7}$ Chopra, S. i White, L.: Artificial Agents and the Contracting Problem: A Solution Via an Agency Analysis, University of Illinois Journal of Law Technology \& Policy, br. 2, Chicago, 2009. str. 363.-403., str. 363., dostupno na http://ssrn.com/abstract=1589564, (4.2.2015.).

${ }^{8}$ Kis, S.: Contracts and Electronic Agents, LLM Theses and Essays., University of Georgia Law, Digital Commons@Georgia Law, Student Works and Organizations, elektroničko izdanje (str. 1.-79.), Athens Georgia, 2004., dostupno na http://digitalcommons.law.uga.edu/stu_llm/25, str. 5.-10., (1.8.2014.).

${ }^{9}$ Objavljen u publikaciji UNICTRAL-ov Model zakon o elektroničkoj trgovini s vodičem za donošenje (1996.), engleski naziv: UNCITRAL Model Law on Electronic Commerce with Guide to Enactment 1996 with addictional article 5bis as adopted in 1998., UN Publication Sales broj E.99.V.4, Ujedinjeni narodi, New York, 1999., dostupno i na www.un.or.at/uncitral/english/texts/electcom/ml-ec.htm, (30.9.2014.).

${ }^{10}$ Jednoobrazni zakon za elektroničke transakcije SAD-a - UNIFORM ELECTRONIC TRANSACTIONS ACT (1999) Drafted by the NATIONAL CONFERENCE OF COMMISSIONERS ON UNIFORM STATE LAWS and by it APPROVED AND RECOMMENDED FOR ENACTMENT IN ALL THE STATES at its ANNUAL
} 
Od međunarodnih izvora tek Konvencija UN-a o elektroničkoj komunikaciji u međunarodnim ugovorima iz 2005. ${ }^{11}$ godine samo u čl. 12 naziva „Korištenje sustava automatskih poruka kod sklapanja ugovora“" otvara mogućnosti korištenja, odnosno regulacije elektroničkih agenata. ${ }^{12}$

Na ovaj način ova konvencija nastoji ohrabriti takvo sklapanje ugovora te osigurati pravnu valjanost ugovora sklopljenih korištenjem elektroničkih agenata. ${ }^{13}$

\section{Zakonodavstvo SAD-a}

\subsection{UETA - Jednoobrazni zakon za elektroničke transakcije}

Polazišna točka američkog prava elektroničke trgovine jest Jednoobrazni zakon o elektroničkim transakcijama ${ }^{14}$ jer se radi o pravnom propisu koji prvi spominje termin „elektronički agent“. ${ }^{15}$ UETA nije federalni zakon i ne primjenjuju je sudovi izravno. UETA-u je pripremila i prihvatila američka Nacionalna konferencija povjerenika za harmoniziranje zakona država SAD-a, ${ }^{16}$ a zapravo je po svojoj pravnoj prirodi blizak model zakonu.

CONFERENCE MEETING IN ITS ONE-HUNDRED-AND-EIGHTH YEAR IN DENVER, COLORADO, JULY, 23 -30, 1999 WITH PREFATORY NOTE AND COMMENTS, 1999., Approved by the American Bar Association, Dallas, Texas, 2000., str. 1.- 65., dostupno na http://www.uniformlaws.org/shared/docs/electronic\%20transactions/ueta_final_99.pdf (2.4.2018.) U daljnjem tekstu korsiti se samo naziv - skraćenica UETA, a tekst se prenosi iz ovog izvora.

${ }^{11}$ UN Convention on Electronic Communications in International Contracts, (Konvencija Ujedinjenih naroda o uporabi elektroničke komunikacije u međunarodnim ugovorima) objavljena u publikaciji br. E.07.V.2 - Ujedinjeni narodi, New $\quad$ York, $2007 . \quad$ dostupna $\quad$ i na http://www.uncitral.org/uncitral/en/uncitral_texts/electronic_commerce/2005Convention.html, (10.1.2016.)

Stupila na snagu 2013. Kasnije se za imenovanje ove konvencije koristi skraćenica UN CEC, a njezin tekst se prenosi iz ovog izvora.

${ }^{12}$ Ugovoru sklopljenom putem sustava automatskih poruka i fizičke osobe, ili interakcijom između sustava automatskih poruka, neće biti osporena valjanost ni izvršivost isključivo na temelju činjenice da fizička osoba nije sudjelovala (intervenirala) u bilo kojoj od pojedinačnih radnji poduzetih putem sustava automatskih poruka ili u konačnom ugovoru (prijevod T.M.).

${ }^{13}$ Tako i Kilian, W., u knjizi Boss, H. A.i Kilian, W.: The United Nations Convention on the Use of Electronic Communications in International Contracts, Wolters Kulwer, SAD, Austin i dr., 2008., str. 191.

${ }^{14}$ UNIFORM ELECTRONIC TRANSACTIONS ACT (1999) Drafted by the NATIONAL CONFERENCE OF COMMISSIONERS ON UNIFORM STATE LAWS and by it APPROVED AND RECOMMENDED FOR ENACTMENT IN ALL THE STATES at its ANNUAL CONFERENCE MEETING IN ITS ONE-HUNDREDAND-EIGHTH YEAR IN DENVER, COLORADO, JULY, 23 -30, 1999 WITH PREFATORY NOTE AND COMMENTS, 1999., Approved by the American Bar Association, Dallas, Texas, 2000., str. 1.- 65., dostupno na http://www.uniformlaws.org/shared/docs/electronic\%20transactions/ueta_final_99.pdf (2.4.2018.) U daljnjem tekstu korsiti se samo naziv - skraćenica UETA, a tekst se prenosi iz ovog izvora.

${ }^{15}$ Prema Katulić, T.: Elektronički agenti i sklapanje ugovora putem interneta, Informator, br. 5142/443 od 10.1.2005. str. 12-19., str. 19.

${ }^{16}$ The Uniform Law Commission (ULC, također poznata kao National Conference of Commissioners on Uniform State Laws - NCCUSL) je neprofitna organizacija osnovana 1892. Njezina svrha je izrada model zakona za države SAD te da na taj način promiče jednoobraznost regulacije koje donose države SAD. Vidjeti detaljno The Uniform 
Nacrt Zakona na 11 stranica donesen je 1999., a Zakonom su regulirani digitalni (elektronički) potpisi, elektronički ugovori, automatizirane transakcije te transakcije sklopljene elektroničkim putem $^{17}$. Ovaj model zakona prihvatile su praktički sve države SAD-a, točnije njih $47^{18}$, i to tako da su donosile svoje zakone kojima su u cijelosti u njima preuzele odredbe UETA-e.

Prva važna odredba ovog zakona u pogledu elektroničkih agenata sadržana je u njegovom čl.

2. st. 2., a definira automatsku transakciju koja je širi pojam i u sebi sadrži i pojam elektroničkog agenta. Time se kao genus proximum posredno odnosi i na definiciju elektroničkog agenta. ${ }^{19}$ Elektronički agent je ,računalni program ili elektroničko ili drugo automatizirano sredstvo neovisno korišteno za iniciranje akcije ili odgovaranje na elektroničke zapise ili izvedbe, u cijelosti ili djelomično, bez pregleda ili djelovanja čovjeka. “20 UETA dakle, definira širi pojam - automatsku transakciju (čl. 2.2.), a potom i uži pojam elektroničkog agenta (čl. 2.6.). U sekciji 14. UETA-e izričito se utvrđuje valjanost ugovora sklopljenih između elektroničkih agenata te između elektroničkog agenta i fizičke osobe koja volju za sklapanje ugovora izražava na tradicionalan način. ${ }^{21}$ Jedini uvjeti koje UETA postavlja za valjanost tih ugovora jest da fizička osoba koja sklapa ugovor s elektroničkim agentom može odbiti sklapanje tog ugovora i da

Law Commission (ULC - National Conference of Commissioners on Uniform State Laws) - About the ULC website, dostupno na http://www.uniformlaws.org/Narrative.aspx?title=About\%20the\%20ULC (24.4.2018.)

17 Tako i Chopra, S. i White, L.: Artificial Agents and the Contracting Problem: A Solution Via an Agency Analysis, University of Illinois Journal of Law Technology \& Policy, br. 2, Chicago, 2009. str. 363-403., str. 388., dostupno na http://ssrn.com/abstract=1589564, (4.2.2015.).

${ }^{18}$ Tri države: Illinois, New York i Washington, nisu usvojile UETA, ali imaju propise koji reguliraju elektroničke transakcije - Vidjeti detaljno The Uniform Law Commission (ULC - National Conference of Commissioners on Uniform State Laws) - Enactment status map - ULC website, dostupno na http://www.uniformlaws.org/Act.aspx?title=Electronic\%20Transactions\%20Act (15.4.2018.).

${ }^{19}$ Section 2.2. UETA - „Automated transaction” means a transaction conducted or performed, in whole or in part, by electronic means or electronic records, in which the acts or records of one or both parties are not reviewed by an individual in the ordinary course in forming a contract, performing under an existing contract, or fulfilling an obligation required by the transaction.

${ }^{20}$ Section 2.6. UETA - Electronic Agent

Electronic agent means a computer program or an electronic or other automated means used independently to initiate an action or respond to electronic records or performances in whole or in a part, without review or action by an individual.

${ }^{21}$ Section 14 - Automated Transaction.

In an automated transaction, the following rules apply:

1) A contract may be formed by the interaction of electronic agents of the parties, even if no individual was aware of or reviewed the electronic agents' actions or the resulting terms and agreement.

2) A Contract may be formed by the interaction of an electronic agent and an individual, acting on the individual's own behalf or for another person, including by an interaction in which the individual performs actions that the individual is free to refuse to perform and which the individual knows or has reason to know will case the electronic agent to complete the transaction or performance.

3) The terms of the contract are determined by the substantive law applicable to it. 
fizička osoba ima opravdani razlog vjerovati da će djelovanjem elektroničkog agenta nastati ugovor. $^{22}$

Navedeni uvjeti usmjereni su na postizanje savjesnosti te pravne sigurnosti pri korištenju elektroničkih agenata, što je svakako za prihvatiti.

Konvencija UN CEC koristi samo termin „sustav automatskih poruka,“ a ne i termin elektroničkog agenta. Taj termin, kao i termini ,automatska transakcija“ i ,automatska računalna transakcija“" imaju isto značenje tako da ne utječu na sadržaj pojma elektroničkog agenta.

Kada se usporedi tekst čl. 12. Konvencije UN CEC vidljivo je da on sadržajno odgovara čl. 2. st. 2. UETA $^{23}$ te da je sukladno tome Konvencija zapravo stala na pola puta u danas prihvatljivoj regulaciji elektroničkog agenta. Konvencija, naime, ne koristi izravno termin elektroničkog agenta, a niti ga definira kao što to čini UETA u čl. 2.6., ali zato jednako kao i čl. 2. st. 2. UETAe stvara pretpostavke za valjanost ugovora sklopljenih kroz korištenje elektroničkih agenata jer koristi termin „sustav automatskih poruka“ koji obuhvaća i elektroničkog agenta te posredno kroz definiranje tog pojma definira i elektroničkog agenta iako ga izravno ne spominje. Na taj način su elektronički agenti postali, u slučaju primjene Konvencije UN CEC, implicite u nju uključeni, te im je otvoren put u korištenju kao pravno sigurno sredstvo za sklapanje valjanih ugovora kroz regulaciju šireg pravnog instituta ,sustava automatskih poruka“.

Stoga Konvencija UN CEC predstavlja značajan korak naprijed u odnosu na postojeću regulativu Europske unije i njezinih članica iz ovog područja uključivši i BiH i RH, dok u odnosu na američko zakonodavstvo zapravo ne donosi ništa novog. Dapače, moglo bi se zaključiti da je američko zakonodavstvo izravno poslužilo kao uzor Konvenciji UN CEC te da je Konvencija ostala na općenitijoj razini regulacije nego li UETA.

Tvorci UETA-e unatoč korištenja termina „elektronički agent“" sagledavaju ga kao alat rada svojih korisnika, odnosno kao samo jedan od načina sklapanja ugovora elektroničkim putem, a što znači da elektronički agent nema i ne može imati pravnu sposobnost, nema samostalnu

\footnotetext{
${ }^{22}$ Radi se zapravo o uvjetima za valjanost tzv. click through, odnosno click wrap i browse wrap ugovora, vidjeti detaljno kod Matić, T.: Formularni ugovori u elektroničkom obliku, Zbornik Pravnog fakulteta u Zagrebu, vol. 58, br. 3., Zagreb 2008.

${ }^{23}$ Tako i Chopra, S. i White, L.: Artificial Agents and the Contracting Problem: A Solution Via an Agency Analysis, University of Illinois Journal of Law Technology \& Policy, br. 2, Chicago, 2009. str. 363-403., str. 386., dostupno na http://ssrn.com/abstract=1589564, (4.2.2015.): ,...the UN Convention is no inconsistent with the agency law approach to the contracting problem."
} 
ugovornu sposobnost, te da je njegovo djelovanje uvijek u ime i za račun određene pravne ili fizičke osobe. ${ }^{24}$

Novi članak 2. Jednoobraznog trgovačkog zakonika SAD-a, ${ }^{25}$ kako je revidiran u svibnju 2003., uključuje propise koji se odnose na ugovore o prodaji roba (kupoprodajne ugovore), koje su sklopili elektronički agent s jedne ugovorne strane te elektronički agent s obje ugovorne strane. Pritom je definicija elektroničkog agenta u članku 2. preuzeta iz UETA-e, tako da, radilo se o UETA-i te na državnim propisima donesenim temeljem UETA-e ili UCC-u, „elektronički agent" ima isto značenje i jednako je i definiran. ${ }^{26}$ Dakle, elektronički agent u ova dva pravna izvora potpuno je jednako definiran, kako je vidljivo iz izvornih tekstova definicija. Stoga bi temeljem prikazane regulacije, kao i zakonskih definicija elektroničkih agenata te teksta Konvencije, univerzalno kao pravnu doktrinarnu definiciju elektroničkog agenta trebalo prihvatiti ovu - elektronički agent je računalni program i/ili elektroničko ili drugo automatizirano sredstvo, odnosno automatizirani sustav slanja elektroničkih poruka koji se koristi za samostalno - autonomno (u većoj ili manjoj mjeri) poduzimanje pravno relevantnih radnji u formi elektroničkog zapisa i/ili ljudski perceptivnih poruka - poruka prema trećima ili odgovora na pravno relevantne radnje u formi elektroničkih zapisa i/ili ljudski perceptivnih zapisa - poruka ili djelovanja prema njemu trećih osoba, bilo u njegovoj cjelini ili dijelu, a da te pravno relevantne radnje u trenutku njihova poduzimanja ne nadgleda ili u njima aktivno ne sudjeluje fizička osoba u bilo kojem

\footnotetext{
${ }^{24}$ Tako i Katulić, T.: Elektronički agenti i sklapanje ugovora putem interneta, Informator, br. 5142/443 od 10.1.2005., Zagreb, str. 12-19., str. 19.: Što se tiče elektroničkih agenata, koji su ovdje prvi put spomenuti u nekom zakonskom prijedlogu, zakon drži da se učinak djelovanja elektroničkog agenta, kao i same njegove radnje drže pravno obvezujućim za vlasnika - principala elektroničkog agenta, bez obzira na to je li neka od transakcija osobno odbrena od vlasnika - principala ili nije.

${ }^{25}$ The Uniform Commercial Code (UCC), Jednoobrazni trgovački zakonik prvi je put objavljen 1952., a stvoren je kako bi harmonizirao pravo trgovačkih transkacija u svih 50 država SAD-a. Zakonik je zajednički produkt National Conference of Commissioners on Uniform State Laws (NCCUSL) i American Law Institute .

Zakonik nije zakon nego samo preporuka (model zakon) za prihvaćanje kao zakona u saveznim državama SADa. Zakonik je prihvatilo svih 50 država SAD kao i District of Columbia te Puerto Rico. Louisiana je prihvatila najveći broj odredbi UCC-a osim čl. 2. nastojeći zadržati vlastitu civil law tradiciju koja uređuje ugovor o prodaji roba.- prema Wikipedia, dostupno na http://en.wikipedia.org/wiki/Uniform_Commercial_Code, (5.2.2014.).

${ }^{26}$ Članak 2. UCC 2003. (prema tekstu UCC-a u izvoru: Cornel Law, Cornel Law School, Legal Information Institute: Uniform Commercial Code, UCC Article 2, Sales. 2003 Revision, dostupno na: http://www.law.cornell.edu/ucc/2/article2, (30.6.2014.) glasi:

(f) "Electronic" means relating to technology having electrical, digital, magnetic, wireless, optical, electromagnetic, or similar capabilities.

(g) "Electronic agent" means a computer program or an electronic or other automated means used independently to initiate an action or respond to electronic records or performances in whole or in part, without review or action by an individual.

(h) "Electronic record" means a record created, generated, sent, communicated, received, or stored by electronic means.
} 
svojstvu, a koji djeluje u ime i za svojeg vlasnika (korisnika). ${ }^{27}$ Ova doktrinarna definicija bila bi dakle primjenjiva i za bosanskohercegovačko, hrvatsko i za EU pravo.

Automatizirani pravni posao ili transakcija koja nastaje kroz uporabu automatiziranog sustava razmjene elektroničkih poruka definira se kao pravni posao ili transakcija obavljena, u cjelini ili dijelu, isključivo elektroničkim sredstvima komuniciranja i/ili elektroničkim zapisima koji djeluju u ime i za račun svojeg vlasnika (korisnika), u kojima iniciranje slanja i samo slanje elektroničkih zapisa i elektroničkih poruka te reakcije na te elektroničke zapise i elektroničke poruke jedne ili obaju ugovornih strana, nisu nadgledane ili vođene putem fizičke osobe na uobičajeni način prilikom sklapanju tog pravnog posla, njegovog nastanka i njegovog postojanju te izvršenju ili izvršenju obveza koje proizlaze iz tog pravnog posla, odnosno transakcije. Automatizirani pravni posao po svojoj pravnoj prirodi odgovara nekom od tradicionalnih pravnih poslova; najčešće je to ugovor o kupoprodaji, a jedina razlika u odnosu na tradicionalno shvaćanje tog pravnog instituta jest način njegova nastanka. U svojoj pravnoj prirodi on se ni u čemu ne razlikuje od takvog tipa pravnog posla nastalog na tradicionalni način. Kod zatvorenog EDI-ja tako govorimo o provedbenim ugovorima ${ }^{28}$ kod ugovora sklopljenim putem elektroničkog agenta o automatiziranim ugovorima, ${ }^{29}$ koji nastaju kod posljedica poduzimanja pravnih radnji putem automatiziranih sistema poruka, a koji se pravnom prirodom ne razlikuju od tradicionalnih ugovora, odnosno pravnih poslova.

\footnotetext{
${ }^{27}$ Informatička definicija elektroničkog agenta uglavnom glasi: Računalni program koji djeluje u ime svojeg vlasnika te pri tome obavlja složene informacijske i komunikacijske poslove u mreži. - tako Petrić, A.: Agentski temeljeno elektroničko poslovanje, dostupno na https://bib.irb.hr/datoteka/332127.Petric_Ana_-

Agentski_temeljeno_elektronicko_poslovanje.pdf, str. 1-10., str. 3. (14.4.2018.) (nema naznake časopisa objave).

${ }^{28}$ Vidjeti detaljno kod Matić, T.: Pravo virtualnih pravnih odnosa: elektronička trgovina, Narodne novine, Zagreb, 2012., str.118-124.

${ }^{29}$ Tako UETA u Section 14 koristi naziv - Automated transaction, dakle automatizirana transkacija, odnosno ugovor, a e-Terms ICC (Međunardone trgovačke komore u Parizu) u Guide for E-contracting, poglavlje B4 dostupno na www.iccwbo.org, (4.2.2015.) koriste termin - Automated e-contracting, odnosno automatizirano sklapanje ugovora: The technology exists to allow companies to communicate with each other electronically with minimal or no human intervention in each transaction, a means of interaction sometimes referred to as "automated contracting". We have long been used to contracting using machines (for example, transactions using vending machines). "Automated contracting" goes one step further in that it involves both counterparties acting through machines, for instance in "just-in-time" arrangements.
} 


\subsection{Zakon o elektroničkim potpisima u globalnoj i nacionalnoj trgovini SAD-a}

Zakon o elektroničkim potpisima u globalnoj i nacionlanoj trgovini ${ }^{30}$ je federalni zakon SAD-a koji je usvojio Kongres SAD-a a kako bi omogućio pravnu sigurnost korištenja elektroničkih komunikacija i elektroničkih potpisa u odnosima između subjekta iz različitih država SAD-a, odnosno unutar SAD-a i na međunarodnoj trgovini.

E-Sign Act sadrži samo dva propisa, koja se odnose na elektroničke agente, uključujući njihovu definiciju. Prvi je onaj koji se odnosi na definiciju jednaku onoj iz UETA-e, ${ }^{31}$ sadržan je u čl. 2. Definicija elektroničkog agenta identična je u ovom pravnom izvoru onoj u UETA-i i novom čl. 2. UCC, s time da je jedino na kraju definicije dodan tekst: u vrijeme poduzimanja radnje ili odgovora (,at the time or the action or response“). Na ovaj način zapravo nije ništa sadržajno promijenjeno, no preciznije je određen trenutak na koji se odnosi stanje nepostojanja nadzora ili djelovanja fizičke osobe iako se taj trenutak i podrazumijevao u definiciji iz UETA-e i UCC čl. 2. Stoga je ova dopuna prihvatljiva i zapravo je pozitivno vrednovana kada je naprijed postavljana univerzalna doktrinarna definicija elektroničkog agenta.

Druga odredba jest ona kojom se osigurava pravna valjanost pravnih poslova sklopljenih putem elektroničkih agenata. ${ }^{32}$ Iz navedenog je vidljivo da je ovaj federalni zakon, kada govorimo o regulaciji elektroničkog agenta, kompatibilan ili sadržajno izjednačen s UETA-om, pa time i državnim zakonima koji su doneseni implementacijom UETA-e. Stoga sve što je ranije rečeno za UETA-u u pogledu elektroničkog agenta vrijedi i za E-sign Act. ${ }^{33}$

\footnotetext{
${ }^{30}$ Electronic Signatures in Global and National Commerce Act /ili skraćeno E-sign zakon (Act)/, ESIGN, Public Law 106-229, 114. Stat 464, 15 USC 7001 note, donesen 30.6.2000., (dostupno na http://www.fdic.gov/regulations/compliance/manual/pdf/X-3.1.pdf - (30.6.2014.)), skraćeni naziv ovog zakona je E-Sign Act, a koji se i ovdje kao takav koristi u ovom radu. Tekst zakona navodi se dalje prema ovom izvoru.

${ }^{31}$ Definicija termina elektroničkog te elektroničkog agenta u E-sign Acta dana je u:
}

SEC. 106. DEFINITIONS:

(2) "Electronic" - The term "electronic" means relating to technology having electrical, digital, magnetic, wireless, optical, electromagnetic, or similar capabilities...

(3) "Electronic Agent" - The term "electronic agent" means a computer program or an electronic or other automated means used independently to initiate an action to respond to electronic records or performances in whole or in part without review or action by an individual at the time or the action or response.

${ }^{32}$ SEC. 101. GENERAL RULE OF VALIDITY (h) ELECTRONIC AGENTS. - A contract or other record relating to a transaction in or affecting interstate or foreign commerce may not be denied legal effect, validity, or enforceability solely because its formation, creation, or delivery involved the action of one or more electronic agents so long as the action of any such electronic agent is legally attributable to the person to be bound.

${ }^{33} \mathrm{O}$ elektroničkom potpisu vidjeti detaljno : Campbell, D. (ur.) : E commerce and the Law of Digital Signatures, Oceana Publications, Inc, New York, 2005. te Trnavci, G.: Zaključenje, punovažnost i dokazivanje elektroničkih ugovora: komparativna analiza, Zbornik Pravnog fakulteta Sveučilišta u Rijeci, vol. 30., br. 1., str. 449-472., Rijeka, 2009. 


\subsection{Jednoobrazni zakon za računalne transakcije - UCITA}

NCCUSL - Nacionalna konferencija povjerenika za jednoobrazne državne zakone SADa (the National Conference of Commissioners on Uniform State Laws) je usvojila, također, Jednoobrazni zakon o računalnom prijenosu informacija 24. srpnja 1999. ${ }^{34}$ Tim se model zakonom $^{35}$ predlaže državama SAD-a regulirati elektroničku trgovinu, a sadrži nekoliko propisa koji se tiču korištenja elektroničkih agenata. Zakon je nastao tako što je NCCUSL započeo izradu novih pravila za elektroničku trgovinu, tako da su povjerenici NCCUSL-a ustvari namjeravali samo revidirati članak 2. UCC-a, ${ }^{36}$ što i jest učinjeno, a kako bi uzeli u obzir korištenje novih elektroničkih tehnologija. Nakon nekog vremena shvatili su da se elektroničke transakcije razlikuju od tradicionalnih i da se ne mogu uklopiti u članke UCC-a, ${ }^{37}$ već da treba pripremiti praktično poseban legislativni akt. Tako je nastala UCITA - zakon koji je i (pretjerano) ambiciozniji i kontroverzniji ${ }^{38}$ od UETA-e. ${ }^{39}$ No, do danas, uglavnom iz tih

${ }^{34}$ UNIFORM COMPUTER INFORMATION TRANSACTIONS ACT (Last Revisions or Amendments Completed Year 2002) drafted by the NATIONAL CONFERENCE OF COMMISSIONERS ON UNIFORM STATE LAWS and by it APPROVED AND RECOMMENDED FOR ENACTMENT IN ALL THE STATES at its ANNUAL CONFERENCE MEETING IN ITS ONE-HUNDRED-AND-ELEVENTH YEAR TUCSON, ARIZONA, JULY 26 - AUGUST 2, 2002 WITH PREFATORY NOTE AND COMMENTS 2002 By NATIONAL CONFERENCE OF COMMISSIONERS ON UNIFORM STATE LAWS October 15, 2002, dostupan na www.uniformlaws.org/shared/docs/computer_infomrmation_transactions/ucita:final_02.pdf (4.9.2014.), dalje se u pravilu koristi skraćenica UCITA. Svi kasniji citati dani su na temelju ovog teksta.

${ }^{35}$ The Uniform Computer Information Transactions Act (UCITA) je također prijedlog zakona (model zakon) namijenjen državama SAD-a. Osnovna namjera jest da postane ugovorno pravo u državama SAD-a i da se tako stvori jasno i jednoobrazno reguliranje područja, kao što su ugovori o prijenosu prava korištenja softvera, pristup on-line te druge transkacije vezane uz računalne transkacije. Ovaj zakon trebao je donijeti jednoobraznost informatičko tehnološkim transkacijama na jednaki način kao što je UCC donio jednoobraznost kod prodaje roba. - vidjeti detaljno kod Pratik A. S., The Uniform Computer Information Transactions Act, 15 Berkeley Technology Law Journal 85, Volume 15, Issue 1, Article 5, Berkeley, SAD, 2000. str. 86-107. dostupno na: http://scholarship.law.berkeley.edu/btlj/vol15/iss1/5 (20.4.2018.).

${ }^{36}$ Ovaj članak regulira ugovor o prodaji (roba), prikazano nešto ranije u ovom radu.

${ }^{37}$ Prema Kis, S.: Contracts and Electronic Agents, LLM Theses and Essays., University of Georgia Law, Digital Commons@Georgia Law, Student Works and Organizations, elektroničko izdanje (str. 1.-79), Athens Georgia, 2004., dostupno na http://digitalcommons.law.uga.edu/stu_llm/25, str. 13., (1.8.2014.).

${ }^{38}$ Popis primjedbi na tekst UCITA-e prilično je dug i odnosi se uglavnom na prijenos prava na softveru. Ilustracije radi daje se jedan: James Huggins Refrigerator Door: Huggins, S. J.: UCITA: Uniform Computer Information Transactions Act, What Are the UCITA Problems?:

UCITA dramatically shifts the balance of existing contract law in favor of software vendors when they contract with businesses and consumers. In particular, UCITA:

- Validates "shrink-wrapped", standard, take-it-or-leave-it licenses

- Introduces new uncertainty regarding the duration of the acquirer's right to use the software

- Allows software vendors to shut down software, even mission critical software, remotely..., without going to court first and without court approval etc...,

dostupno na http://www.jamesshuggins.com/h/tek1/ucita.htm, (2.9.2014.).

${ }^{39}$ Slično i kod Pratik A. S., The Uniform Computer Information Transactions Act, 15 Berkeley Technology Law Journal 85, Volume 15, Issue 1, Article 5, Berkeley, SAD, 2000. str. 86-107. dostupno na: http://scholarship.law.berkeley.edu/btlj/vol15/iss1/5, str. 86-.107. (20.4.2018.) str. 87.- 91. 
razloga, samo su američke države Maryland i Virginia usvojile UCITA-u pa sukladno tome važnost ovog potencijalnog propisa, kao trenutnog izvora prava, otpada tim više što je doživio ogromne kritike $^{40}$ te nije izgledna njegova daljnja recepcija u zakonodavstvu država SAD-a. ${ }^{41}$

Prema UCITA-i, također, vrijedi opće načelo da su ugovori sklopljeni uporabom elektroničkih agenata valjani, čak i ako osoba nije bila svjesna ili nije pregledala aktivnosti agenta ili rezultate tih aktivnosti. Aktivnosti elektroničkog agenta također se pripisuju njegovu vlasniku, odnosno korisniku. $^{42}$

U sekciji 112. pod nazivom manifestacija suglasnosti ${ }^{43}$ (manifesting assent) definiran je način na koji elektronički agent manifestira suglasnost. Elektronički agent iskazuje suglasnost (za pravnu radnju, odnosno sklapanje ugovora) na zapis ili uvjet, ako, nakon što je imao mogućnosti pregledati ih, elektronički agent:

a/ autentificira (elektronički) zapis ili uvjet ili

b/ poduzme radnje koje u danim uvjetima ukazuju na prihvat zapisa ili uvjeta. ${ }^{44}$

\footnotetext{
${ }^{40}$ prema Kis, S.: Contracts and Electronic Agents, LLM Theses and Essays., University of Georgia Law, Digital Commons@Georgia Law, Student Works and Organizations, elektroničko izdanje (str. 1-79), Athens Georgia, 2004., dostupno na http://digitalcommons.law.uga.edu/stu_llm/25, str. 13. (1.8.2014.).

41 Naime, u uobičajenoj proceduri prihvaćanja model zakona koje je izradio NCCUSL (NATIONAL CONFERENCE OF COMMISSIONERS ON UNIFORM STATE LAWS), American Bar Association daje preporuku za usvajanje istih. U slučaju UCITA-e takva je preporuka uskraćena. Nakon toga NCCUSL je povukao prijedlog upućen ABA za donošenje rezolucije o prijedlogu usvajanja ovog model zakona u državna zakonodavstva još 2003. godine. Kako je mišljenje i rezolucija ABA redovan uobičajeni put da neki model zakon bude prihvaćen, na ovaj način zapravo je zaustavljena recepcija UCITA-e u zakonodavstvo država SAD-a. Stoga se smatra da UCITA danas dominantno ima samo akademsku, a ne praktično operativnu vrijednost.

${ }^{42}$ UCITA - SECTION 107. LEGAL RECOGNITION OF ELECTRONIC RECORD AND AUTHENTICATION; USE OF ELECTRONIC AGENTS

107(d) (Party bound by electronic agent.) A person that uses an electronic agent that it has selected for making an authentication, performance, or agreement, including manifestation of assent, is bound by the operations of the electronic agent, even if no individual was aware of or reviewed the agent's operations or the results of the operations. -

UCITA - (Prefaratory Note and Comments) - UNIFORM COMPUTER INFORMATION TRANSACTIONS ACT (Last Revisions or Amendments Completed Year 2002) drafted by the NATIONAL CONFERENCE OF COMMISSIONERS ON UNIFORM STATE LAWS and by it APPROVED AND RECOMMENDED FOR ENACTMENT IN ALL THE STATES at its ANNUAL CONFERENCE MEETING IN ITS ONE-HUNDREDAND-ELEVENTH YEAR TUCSON, ARIZONA, JULY 26 - AUGUST 2, 2002 WITH PREFATORY NOTE AND COMMENTS 2002 By NATIONAL CONFERENCE OF COMMISSIONERS ON UNIFORM STATE LAWS October 15, (4.9.2014).

${ }^{43}$ Ovaj američki termin pandan je europskom kontinentalnom terminu suglasnosti volja za sklapanje ugovora, distinkcija će biti analizirana nešto kasnije.

${ }^{44}$ UCITA - SECTION 112. MANIFESTING ASSENT.

(b) (How electronic agent manifests assent) An electronic agent manifests assent to a record or term if, after having an opportunity to review it, the electronic agent:

1. authenticates the record or term; or

2. engages in operations that in the circumstances indicate acceptance or the record or term.
} 
Dakle, UCITA je ovom odredbom pokušala definirati uvjete za valjanost manifestacije suglasnosti za nastanak pravnog posla, odnosno radnju koja izaziva pravni učinak koji čini elektronički agent. Ovdje se manifestira pravilo common law sustava, prema kojem to pravo ne traži kao dokaz manifestacije volje subjektivnu namjeru pojedinca, nego se fokusira na objektivno učinjenu njezinu manifestaciju. Ovakav stav američka teorija naziva modernom kontraktualnom teorijom o objektivnoj suglasnosti. ${ }^{45}$ Iako UCITA, kao takva, nije prihvaćena, ovakva teorija nesporno dominira pravnim prostorom common law-a.

U Komentarima na Zakon ${ }^{46}$ navodi se da se suglasnost elektroničkog agenta mjeri njegovom sposobnošću reakcije i procjenom implikacija/smislenosti njegovih radnji/poteza jer se suglasnost ne može temeljiti na poznavanju ili znanju. Štoviše, potezi kojima se manifestira suglasnost mogu se dokazivati na bilo koji način, ${ }^{47}$ posebno vodeći računa o (naprijed navedenoj) točki b/.

S obzirom na to da je sekcija 112. za valjanost manifestacija suglasnosti elektroničkog agenta tražila da elektronički agent mora imati mogućnosti pregledati (elektronički) zapis ili uvjet, $\mathrm{u}$ sekciji 113. (b) definirana je mogućnost pregleda pa se tako određuje da elektronički agent ima mogućnost pregledati zapis ili uvjet samo ako su mu oni dostupni na način da bi razumno konfigurirani elektronički agent mogao reagirati na zapis ili uvjet. ${ }^{48}$ Tradicionalnim pravnim rječnikom ovo bi značilo da poruka upućena elektroničkom agentu može proizvesti pravni učinak jedino ako je učinjena na način da prosječni elektronički agent može takvu poruku pročitati. Dakle, nije bitna sposobnost pojedinog elektroničkog agenta, već onog prosječno konfiguriranog kako bi elektronička poruka proizvela pravni učinak.

45 Tako UCITA - (Prefaratory Note and Comments) - UNIFORM COMPUTER INFORMATION TRANSACTIONS ACT (Last Revisions or Amendments Completed Year 2002) drafted by the NATIONAL CONFERENCE OF COMMISSIONERS ON UNIFORM STATE LAWS and by it APPROVED AND RECOMMENDED FOR ENACTMENT IN ALL THE STATES at its ANNUAL CONFERENCE MEETING IN ITS ONE-HUNDRED-AND-ELEVENTH YEAR TUCSON, ARIZONA, JULY 26 - AUGUST 2, 2002 WITH PREFATORY NOTE AND COMMENTS 2002 By NATIONAL CONFERENCE OF COMMISSIONERS ON UNIFORM STATE LAWS October 15, str. 61. (4.9.2014.).

${ }^{46}$ Misli se na „Preparatory Note and Comments“ u odnosu na Uniform Computer Information Transactions Act (Last Revisions or Amendments Completed Year 2002) with Prefatory Note and Comments, National Conference of Commissioners of Uniform State Laws, Chicago, SAD, 2002. - Ibid.

${ }^{47}$ Tako Kis, S.: Contracts and Electronic Agents, LLM Theses and Essays., University of Georgia Law, Digital Commons@Georgia Law, Student Works and Organizations, elektroničko izdanje (str. 1-79), Athens Georgia, 2004., dostupno na http://digitalcommons.law.uga.edu/stu_llm/25, str. 25., (1.8.2014.).

48 UCITA - Section 113 Opportunity to review

(b) (Manner of availability by electronic agent) An electronic agent has an opportunity to review a record or term if it is made available in a manner that would enable a reasonably configured electronic agent to react to the record or term. 
Prema UCITA-i, elektronički agent je računalni program ili elektroničko ili drugo automatizirano sredstvo korišteno samostalno za pokretanje radnje ili odgovaranje na elektroničke poruke ili izvedbe bez istodobnog pregleda ili djelovanja čovjeka. ${ }^{49}$ Definicija elektroničkog agenta iz ovog pravnog akta gotovo je tekstom jednaka onoj iz UCC-a i iz UETA-e te posebno onoj iz E-sign Acta, jer je na kraju definicije jednako kao i u definiciji iz $\boldsymbol{E}$-sign Acta dodan tekst ,at the time or the action or response“, što je nedvojbeno točno i prihvatljivo.

No, ova definicija sadrži jednu odrednicu koja nije sadržana u definicijama iz prijašnjih izvora. Naime, u njoj je navedeno za čiji račun i u čije ime se poduzima radnja putem elektroničkog agenta „,...on the person's behalf... “ U objašnjenjima i komentarima UCITA-e stoji da je automatizirani sustav izabran, programiran i na svaki drugi način upotrijebljen za svrhe od osobe koja biva obvezana poduzimanjem tih pravnih radnji. ${ }^{50}$ Ovo pravilo još jednom potvrđeno je u sekciji 107. UCITA-e točka d) prema kojoj osoba, koja koristi elektroničkog agenta kojeg je odabrala za sklapanje, potvrdu ili izvršenje ugovora uključivši i manifestaciju suglasnosti za sklapanje pravnih poslova, vezana je radnjama elektroničkog agenta čak i ako niti jedna fizička osoba nije bila svjesna ili je nadgledala radnje elektroničkog agenta ili rezultate tako poduzetih pravnih radnji. ${ }^{51}$ Ovo je svakako prihvatljiv stav i predstavlja zapravo popravljanje definiranja elektroničkog agenta u odnosu na ranije prikazane definicije, ${ }^{52}$ mada

\footnotetext{
${ }^{49}$ UCITA, Section 102. Definitions, definition no. 27: Electronic agent means a computer program, or electronic or other automated means, used independently to initiate an action, or to respond to electronic message or performances, on the person's behalf without review or action by an individual at the time of the action or response to the message or performance.

${ }^{50}$ Dakle, prema komentaru (Preparatory Note and Comments) UCITA-e automatizirani sustav mora odabrati, programirati ili na drugi način koristiti osoba, koja je pravno vezana operacijama sustava. Neki autori navode da UCITA elektroničkog agenta tretira kao hibridnu vrstu, s elementima tradicionalnog agenta - UNIFORM COMPUTER INFORMATION TRANSACTIONS ACT (Last Revisions or Amendments Completed Year 2002) drafted by the NATIONAL CONFERENCE OF COMMISSIONERS ON UNIFORM STATE LAWS and by it APPROVED AND RECOMMENDED FOR ENACTMENT IN ALL THE STATES at its ANNUAL CONFERENCE MEETING IN ITS ONE-HUNDRED-AND-ELEVENTH YEAR TUCSON, ARIZONA, JULY 26 - AUGUST 2, 2002 WITH PREFATORY NOTE AND COMMENTS, 2002., By NATIONAL CONFERENCE OF COMMISSIONERS ON UNIFORM STATE LAWS October 15, str. 23., dostupno na

www.uniformlaws.org/shared/docs/computer_infomrmation_transactions/ucita:final_02.pdf - (4.9.2014.).

${ }^{51}$ UCITA - SECTION 107. LEGAL RECOGNITION OF ELECTRONIC RECORD AND
}

AUTHENTICATION; USE OF ELECTRONIC AGENTS.

(d) (Party bound by electronic agent) A person that uses an electronic agent that is has selected for making an authentication, performance, or agreement, including manifestation of assent, is bound by the operations of electronic agent, even if no individual was aware of or reviews the agent's operations or the results of the operations.

${ }^{52}$ Slično i Katulić, T.: Elektronički agenti i sklapanje ugovora putem interneta, Informator, br. 5142/443 od 10.1.2005. str. 12.-19., Zagreb, str. 20. - Ovdje donesena definicija elektroničkog agenta pomalo je jasnija i određenija nego ona sadržana u UETA-i. Prema ovom propisu, elektronički agent je kompjuterski program ili drugo ili elektroničko ili automatizirano sredstvo korišteno od osobe da inicira radnju ili da odgovori na elektroničke poruke $\mathrm{u}$ ime te osobe bez nadzora ili kontrole tog korisnika u vrijeme poduzimanja radnje ili odgovaranja na elektroničku poruku. 
ovo definiranje slijedi osnovna pravila njegovog definiranja, a koja su postavljena u UETA-i i E-sign Actu elektroničkog agenta kao komunikacijskog alata, ${ }^{53}$ a ne agenta u tradicionalnom smislu definiranja tog pojma. ${ }^{54}$ UCITA sadrži u sekciji $206^{55}$ nešto razrađeniju sekciju 14 UETA-e kada regulira sklapanje ugovora između dva elektronička agenta i između elektroničkog agenta i pojedinca, ${ }^{56}$ no niti time se ne pruža potpuna regulacija načina rada i djelovanja elektroničkih agenata $u$ njihovoj interakciji $s$ drugim elektroničkim agentima i pojedincima, a posebno ne u pogledu nastanka/valjanosti ugovora uslijed mana volje (prijevare) ili pogreške u radu elektroničkog agenta koje se izričito navode kao primjenjiv kriterij za nevaljanost, odnosno ne nastanak ugovora u slučaju da ga sklapaju dva elektronička agenta (čl.206.a), a ne navode se kada se radi o sklapanju ugovora između elektroničkog agenta i pojedinca (čl. 206.b). ${ }^{57}$

UCITA, dakle, najdetaljnije regulira djelovanje elektroničkih agenta, no ona, u pravilu i s obzirom na svoj status, predstavlja soft law izvor - izvor koji bi u ovom dijelu trebalo prilično

\footnotetext{
${ }^{53}$ Prema Kis, S.: Contracts and Electronic Agents, LLM Theses and Essays., University of Georgia Law, Digital Commons@Georgia Law, Student Works and Organizations, elektroničko izdanje (str. 1-79), Athens Georgia, 2004., dostupno na http://digitalcommons.law.uga.edu/stu_llm/25, str. 13.

${ }^{54}$ Tako u komentaru (Preparatory Note and Comments) UCITE stoji: „The legal relationship between the person and the electronic agent is not equivalent to common law agency since the ,agent" is not a human. However, parties that use electronic agents are ordinarily bound by the results of their operations." - UNIFORM COMPUTER INFORMATION TRANSACTIONS ACT (Last Revisions or Amendments Completed Year 2002) drafted by the NATIONAL CONFERENCE OF COMMISSIONERS ON UNIFORM STATE LAWS and by it APPROVED AND RECOMMENDED FOR ENACTMENT IN ALL THE STATES at its ANNUAL CONFERENCE MEETING IN ITS ONE-HUNDRED-AND-ELEVENTH YEAR TUCSON, ARIZONA, JULY 26-AUGUST 2, 2002 WITH PREFATORY NOTE AND COMMENTS, 2002., By NATIONAL CONFERENCE OF COMMISSIONERS ON UNIFORM STATE LAWS October 15, str. 23., dostupno na www.uniformlaws.org/shared/docs/computer_infomrmation_transactions/ucita:final_02.pdf - (4.9.2014.).

${ }^{55}$ UCITA - Section 206. Offer and acceptance: Electronic agents.

(a) (Formation by interaction of electronic agents.) A contract may be formed by the interaction of electronic agent. If the interaction results in the electronic agents' engaging in operation that under circumstances indicate acceptance of an offer, a contract is formed, but a court may grant appropriate relief if the operations resulted from fraud, electronic mistake, or the like.

(b) (Formation by interaction of individual and electronic agent.) A contract may be formed by the interaction of an electronic agent and an individual acting on the individual's own behalf or for another person. A contract is formed if the individual takes an action or makes a statement that the individual can refuse to take or say and that the individual has reason to know will:

- Cause the electronic agent to perform, provide benefits, or allow the use or access that is the subject of the contract, or send instruction to do so; or

- Indicate acceptance, regardless of other expressions or actions by the individual to which the individual has reason to know the electronic agent cannot react.

(Terms of the contract) Terms of the contract formed under subsection (b) are determined under Section 208-209 but do not include a term provided by the individual if the individual had reason to know that the electronic agent could not react to the term.

${ }^{56}$ Ibid

57 Tako i Katulić, T.: Elektronički agenti i sklapanje ugovora putem interneta, Informator, br. 5142/443 od 10.1.2005. Zagreb, str. 12-19., str. 20.
} 
uvažavati s obzirom na to da donosi rješenja ispred svih zakonodavnih pokušaja koji prate tehnološki razvoj na odgovarajući način.

Zaključno, nakon analize navedenih američkih propisa, moglo bi se reći da je iz njih za američko pravo utvrđena definicija elektroničkog agenta, a kako su naprijed i navedene, te da bi, s obzirom na nepostojanje definiranja u drugim pravnim izvorima, posebno prava u Europi, te definicije trebalo prihvatiti kao univerzalne.

\section{Europa (Europska unija) - nedostatak izravne regulacije i definicije}

Danas u Europskoj uniji ne postoji na razini prava Unije propis kojim su definirani elektronički agenti. Zakoni članica EU-a doneseni u implementaciji Direktive o elektroničkoj trgovini ${ }^{58}$ sadrže opću formulaciju iz Direktive o valjanosti ugovora zaključenih elektroničkim putem, no ne postoji izravna poveznica u pogledu valjanosti sklapanja ugovora putem elektroničkih agenata, ${ }^{59} \mathrm{a}$ u pravilu se s elektroničkom trgovinom te elektroničkim agentom ${ }^{60}$ vezuje čl. 9. (1) Direktive. ${ }^{61}$ Isto pravilo važi za pravo Bosne i Hercegovine i Hrvatske.

Europska komisija je 1997. godine donijela Inicijativu o elektroničkoj trgovini $\mathrm{s}$ ciljem stvaranja jedinstvenog okvira za elektroničku trgovinu i promoviranja njezina rasta $\mathrm{u}$

\footnotetext{
${ }^{58}$ Direktiva 2003/31/EC Europskog parlamenta i Vijeća od 8. lipnja 1999. o nekim pravnim aspektima usluga informacijskog društva, posebno elektroničkoj trgovini na unutrašnjem tržištu, Službeni list Europskih zajednica L 178, 17/07/2000 p. 0001 - 0016, iz 2000. godine., Direktiva o elektroničkoj trgovini.

${ }^{59}$ Tako i Chopra, S. i White, L.: Artificial Agents and the Contracting Problem: A Solution Via an Agency Analysis, University of Illinois Journal of Law Technology \& Policy, br. 2, Chicago, 2009. str. 363-403., str. 387., dostupno na http://ssrn.com/abstract=1589564, (4.2.2015.).

${ }^{60}$ Tako i Kilian, W., u knjizi Boss, H. A. i Kilian, W.: The United Nations Convention on the Use of Electronic Communications in International Contracts, Wolters Kulwer, Austin i dr., SAD, 2008., str. 185.

${ }^{61}$ Odjeljak 3.: Ugovori sklopljeni elektroničkim putem

Članak 9. Tretman ugovora

1. Države članice moraju osigurati da njihov pravni sustav dozvoljava sklapanje ugovora elektroničkim putem. Države članice moraju posebice osigurati da pravni zahtjevi koji se primjenjuju na ugovorni proces ne stvaraju prepreke korištenju elektroničkih ugovora $\mathrm{i}$ da ne rezultiraju time da takvi ugovori budu bez pravnog učinka $\mathrm{i}$ pravovaljanosti zbog toga što su sklopljeni elektroničkim putem.
} 
Europi. ${ }^{62}$ Iz te su inicijative iznikle tri direktive: Direktiva o elektroničkoj trgovini, Direktiva o elektroničkom potpisu ${ }^{63}$ i Direktiva o ugovorima sklapanim na daljinu. ${ }^{64}$

Najznačajniji europski propis o elektroničkoj trgovini i sklapanju ugovora elektroničkim putem jest Direktiva o elektroničkoj trgovini. Direktiva je donesena u lipnju 2000. godine s ciljem stvaranja pravnog okvira kako bi se osiguralo slobodno kretanje usluga informacijskog društva između država članica, odnosno uklanjanje svih pravnih prepreka za sklapanje ugovora elektroničkim putem. ${ }^{65}$

Direktiva službeno priznaje valjanost elektronički sklopljenih ugovora i nastoji osigurati valjanost i provedivost tih ugovora u svim zemljama EU-a. Iako se u Direktivi ne spominju izričito elektronički agenti, niti postoji definicija ,elektroničkog sredstva“, može se opravdano zaključiti da su elektronički agenti - jedno od elektroničkih sredstava komuniciranja pa da se stoga i čl. 9. Direktive odnosi i na ugovore sklopljene putem elektroničkog agenata i EDI-ja. Iako je još u dodatku Prijedloga Direktive bilo navođeno da „države članice..., neće spriječiti korištenje elektroničkih sustava poput inteligentnih elektroničkih agenata“, ${ }^{66}$ sama Direktiva ne spominje elektroničke agente. ${ }^{67}$ Očito je da se dopustivost i pravna valjanost ugovora sklopljenih automatiziranim sustavom komuniciranja izvodi iz općeg pravila o valjanosti ugovora sklopljenih elektroničkim putem, s obzirom na to da se očito smatra da je sklapanje ugovora kroz elektroničkog agenta samo jedan od načina sklapanja ugovora elektroničkim putem. Međutim, zasigurno postoji razlog zbog čega je Konvencija UN CEC ${ }^{68}$ pored opće formulacije o valjanosti ugovora sklopljenih elektroničkim putem (članak 8. koji sadržajno

\footnotetext{
${ }^{62}$ A European Initiative on Electronic Commerce: Communication to the European Parliament, the Council, the Economic and Social Committee and the Committee of the Regions, COM (97) 157 final, Brussels, 16.4.1997., dostupno na http://www.cordis.lu/esprit/src/ecomcom.htm, 30.6.2014.

${ }^{63}$ Direktiva 1999/93/EZ Europskog parlamenta i Vijeća od 13.12.1999. o okviru Zajednice za elektroničke potpise, Službeni list Europskih zajednica br. L 13/12 od 19.1.2000. - Direktiva o elektroničkim potpisima. Kasnije zamijenjena Uredbom (EU) br. 910/2014 Europskog parlamenta i vijeća od 23. srpnja 2014. o elektroničkoj identifikaciji i uslugama povjerenja za elektroničke transakcije na unutarnjem tržištu i stavljanju izvan snage Direktive 1999/93/EZ, - eIDAS Uredba, hrv. tekst, 28.8.2014. HR Službeni list Europske unije L 257/73.

${ }^{64}$ Directive 97/7/EC on Distance Contracts, 1997 O.J. (L 144) - Direktiva 97/7/EZ Europskog parlamenta i Vijeća od 20.5.1997. o zaštiti potrošača s obzirom na sklapanje ugovora na daljinu, hrv. tekst. Službeni list EU L-144/19. 65 članak 9. Direktive.

${ }^{66}$ Annex 1 to the Proposal for Directive on Electronic Commerce, COM (1998) 586 final., prema Kis, S.: Contracts and Electronic Agents, LLM Theses and Essays., University of Georgia Law, Digital Commons@Georgia Law, Student Works and Organizations, elektroničko izdanje (str. 1-79.), Athens Georgia, 2004., dostupno na http://digitalcommons.law.uga.edu/stu_llm/25, str. 14., (1.8.2014.).

${ }^{67}$ Tako i Kilian, W., u knjizi Boss, H. A. i Kilian, W.: The United Nations Convention on the Use of Electronic Communications in International Contracts, Wolters Kulwer, Austin i dr., SAD, 2008., str. 185. - The European Union issued a directive requiring each Member State to ensure that its legal system allows contracts to be concluded by electronic means and does not deprive those contracts of legal effectiveness and validity because they were made by electronic means.

68 Jednako kao i UETA.
} 
korespondira članku 9. Direktive EU o elektroničkoj trgovini) posebno istaknula valjanost ugovora sklopljenih kroz elektroničke agente u čl. 12, pa se time postavlja pitanje dostatnosti regulacije iz Direktive EU glede elektroničkih agenata. Naime, svaki automatizirani sustav sklapanja ugovora može izgledati, na prvi pogled, u nesuglasju s tradicionalnim modelom načina sklapanja ugovora zasnovanom na interakciji fizičkih osoba koje izražavaju svoju zajedničku namjeru - volju da budu vezane ugovorom, ${ }^{69}$ te je očito ova činjenica opravdavala takvo postupanje redaktora UN CEC, ali i UETA-e ${ }^{70}$.

Direktivu o elektroničkoj trgovini države članice preuzele su u vlastito zakonodavstvo jednako kao i države koje imaju aspiraciju stupanja u članstvo EU-a, tako da se radi o najznačajnijem unifikatornom pravnom instrumentu u Europi u ovom pravnom području. Europska unija, dakle, jest prepoznala potrebu priznanja valjanosti ugovora sklopljenih putem svih elektroničkih sredstava, a time i posredno putem samostalnih agenata, iako izričite odredbe $u$ odnosu na elektroničke agente nema.

\section{Elektronički agent kao komunikacijski alat - jedan od čistih načina elektroničke komunikacije}

Elektroničke agente treba smatrati komunikacijskim alatima, odnosno kao jedan od načina elektroničkog komuniciranja na koji se primjenjuju pravila prava elektroničke trgovine kao lex specialis.

U ovom modelu uloga elektroničkog agenta se svodi na razinu sadašnjeg društvenog i pravnog shvaćanja te se svaki ugovor sklopljen putem elektroničkog agenta pripisuje njegovu vlasniku, odnosno korisniku. Elektronički agent bi se tretirao kao e-mail ili telefaks ili EDI, odnosno kao jedan od elektroničkih načina komuniciranja ${ }^{71}$ i prijenosa pravno relevantnih poruka, iako elektronički agent nije kao poseban elektronički način sklapanja ugovora naveden niti u

\footnotetext{
${ }^{69}$ Tako i Kilian, W., u knjizi Boss, H. A. i Kilian, W.: The United Nations Convention on the Use of Electronic Communications in International Contracts, Wolters Kulwer, Austin i dr., 2008., SAD, str. 184.

${ }^{70}$ Problem će biti detaljnije prikazan te raspravljen nešto kasnije.

${ }^{71}$ Tako i Katulić, T.: Elektronički agenti i sklapanje ugovora putem interneta, Informator br. 5142/443 od 10.1.2005., Zagreb, str. 12-19., str. 18. On smatra elektroničkog agenta ne kao agenta nego kao sredstvo komunikacije. Ovaj pristup problemu osniva se na prihvaćanju fikcije da su sve odluke koje potječu od elektroničkog agenta zapravo odluke čovjeka ili ljudi koji tog agenta kontroliraju, odnosno kojima taj agent pripada. To znači da je agent u pravnom smislu poistovjećen s telefonom ili faksom. Tada se ne bi moglo reći da je elektronički agent sklopio neki posao u ime i za račun osobe za koju radi, nego da je ta osoba kojoj agent pripada koristila agenta kao sredstvo očitovanja volje i sama sklopila ugovor.
} 
Direktivi o elektroničkoj trgovini, niti u Zakonu o elektroničkoj trgovini $\mathrm{RH}^{72}$, a niti u Zakonu o elektronskom/elektroničkom pravnom i poslovnom prometu $\mathrm{BiH}^{73}$. Kao rezultat ovakvog shvaćanja, treba zanemariti važnost samostalnosti elektroničkog agenta u sklapanju ugovora $i$ prijenosu pravno relevantnih poruka i posljedično tome ignorirati njegovu eventualnu veću ili manju autonomiju. Naime, elektronički agent uvijek je nesamostalan jer ga programira i kontrolira određena osoba - korisnik ili vlasnik, a kako je svaki njegov akt zapravo akt korisnika ili vlasnika, nebitno je kolika je njegova autonomija u odnosu na tog korisnika ili vlasnika s obzirom na to da je upravo određuje taj korisnik ili vlasnik.

Osim toga, i sudska praksa podržava takav pristup. Tako, primjerice, još 1972. godine Apelacijski sud za deseti okrug (Tenth Circuit $^{74}$ ) SAD-a jedno je osiguravajuće društvo smatrao odgovornim za pogrešku za koju se tvrdilo da ju je napravio računalni sustav društva. ${ }^{75} \mathrm{U}$ ovom slučaju $^{76}$ pojedinac (Bockhorst) nije platio premiju osiguranja. Nakon što je jedno jutro imao nesreću i usmrtio pješaka, poslao je društvu ček na neplaćene zakašnjele iznose. U međuvremenu je ček stigao do računovodstva društva i proknjižen je u računalu. Računalo je na temelju takvog upisa, i s obzirom na to da nije dobilo ili moglo dobiti obavijest o nesreći, ponovno aktiviralo osiguranje. Nastao je, naravno, spor oko postojanja osiguranja zbog isplate štete. Bockhorst je tvrdio da je bio pokriven osiguranjem, dok je osiguravajuće društvo kasnije tvrdilo da je u pitanju računalna pogreška. Sud je odlučio u korist Bockhorsta, navodeći da smatra tvrtku odgovornom za postupke njezina računalnog sustava. Računalo postupa u skladu s naredbama i informacijama koje mu daje ljudski faktor. Računalo ne supstituira čovjeka, ne razmišlja kao čovjek, i njegova pogreška smatra se pogreškom ljudskog faktora koji kontrolira računalo. $^{77}$

\footnotetext{
${ }^{72}$ Zakon o elektroničkoj trgovini - Narodne novine (NN) br.173/03, 67/08, 36/09, 130/11, 30/14., dalje se koristi skraćenica ZET.

${ }^{73}$ Službeni glasnik BiH br. 88/07, dalje se koristi skraćenica ZEPPP.

${ }^{74}$ Fedearalni apelacijski sudovi su nadležni za postupanje kao apelacijski sudovi protiv odluka distriktnih sudova, kao stupanj između distriktnih sudova i Vrhvonog suda SAD-a. Deseti teritorijalni jurisdikcijski okrug SAD-a obuhvaća drugi stupanj federalne teritorijalne nadležnosti za šest država, i to Oklahomu, Kansas, New Mexico, Colorado, Wyoming i Utah. - prema The US Court of Appeals for the Tenth Circuit, dostupno na https://www.ca10.uscourts.gov/clerk, (10.1.2016.).

${ }^{75}$ Prema Kis, S.: Contracts and Electronic Agents, LLM Theses and Essays., University of Georgia Law, Digital Commons@Georgia Law, Student Works and Organizations, elektroničko izdanje (str. 1-79.), Athens Georgia, 2004., dostupno na http://digitalcommons.law.uga.edu/stu_llm/25, str. 43. (1.8.2014.).

${ }^{76}$ State Farm Mut. Auto. Ins. Co. v. Bockhorst, 453 F.2d 533 (10th Cir. 1972) prema Kis, S.: Contracts and Electronic Agents, LLM Theses and Essays., University of Georgia Law, Digital Commons@Georgia Law, Student Works and Organizations, elektroničko izdanje (str. 1-79), Athens Georgia, 2004., dostupno na http://digitalcommons.law.uga.edu/stu_llm/25, str. 43., (1.8.2014.).

77 Tako i i Kilian, W., u knjizi Boss, H. A. i Kilian, W.: The United Nations Convention on the Use of Electronic Communications in International Contracts, Wolters Kulwer, Austin i dr., SAD, 2008., 187. - Even a principal who does not know the detail of the activities of his automated message system is not excused from responsibility
} 


\section{Poduzimanje pravno relevantnih radnji za sklapanje ugovora - izražavanje suglasnosti (volje) za sklapanjem ugovora}

Osnovni problem vezano uz uporabu elektroničkih agenata jest mogu li oni dati valjanu ponudu, odnosno valjano izraziti suglasnost potrebnu za nastajanje, odnosno sklapanje ugovora.

Naime, za valjani pravni posao potrebno je da su se ugovorne strane suglasile o bitnim sastojcima ugovora, tj. da su usuglasile svoje volje. Kako je očitovanje vanjska manifestacija unutarnjeg sadržaja volje, redovito je očitovanje kod svakog suugovaratelja sukladno njegovoj pravoj volji. No, često očitovanje jednog ili oba suugovaratelja nije u skladu s njihovom pravom voljom, pa se pojavljuje nesklad između volje i očitovanja, dolazi do mana volje. U takvim prilikama postavlja se pitanje vrijedi li prema suugovaretelju, odnosno trećima ono što je stvarna volja jedne strane ili oba suugovaratelja - teorija volje (Willenstheorie) ili vrijedi ono kako su se jedna strana ili obje strane očitovale, bez obzira na volju - teorija očitovanja (Erklaerungstheorie). ${ }^{78}$

Prema teoriji volje, dođe li do razlike između volje i očitovanja, očitovanje je nevaljano jer volja za sklapanjem pravnog posla nije niti postojala ili, ako je postojala, ima takve mane da je očitovanje ništetno (volja nastala pod prijetnjom, u zabludi, pod prisilom). ${ }^{79}$ Prema sistemu volje, samo je volja stvaralac prava i obveza. Greška u izjavi (razlika između željenog i izjavljenog smisla) spriječava volju da proizvodi svoj pravni učinak jer izjava nije u suglasnosti s onim što se željelo. Izjava volje je, dakle, ili nepostojeća, ako izjavitelj nije uopće imao volju, suprotno mišljenju destinatera, da zaključi ugovor, ili ništava kad postoji manifestacija volje, onda je ona pogrešno učinjena (zabluda, prevara, prijetnja ili prinuda). ${ }^{80}$ Teorija volje odgovara na prvi pogled terminološkom pojmu ,subjektivne teorije“ izražavanja volje kako je nazivaju američki autori, a kako će biti prikazano nešto kasnije. Tradicionalno gledano u Justinijanovom pravu daje se prednost unutarnjoj volji i namjeri stranke - In conventionibus contrahentium

\footnotetext{
for its effects because he adopted the use of the electronic communication process for his own purposes. Otherwise, he could shift risk to third parties and take advantage of the positive effect of division of labor.

${ }^{78}$ Tako Gorenc, V. et. al.; Gorenc, V. (ur.): Komentar Zakona o obveznim odnosima, Narodne novine, Zagreb, 2014., str. 365.

${ }^{79}$ Ibid.

${ }^{80}$ Komentar Zakona o obligacionim odnosima, I knjiga, drugo izdanje, Blagojević, B. (ur) i Krulj, V. (ur), Savremena administracija, Beograd, 1983., str. 105 - 106.
} 
voluntatem potius quam verba spectari placuit. ${ }^{81}$ Prema teoriji očitovanja ${ }^{82}$ (ili izjave ${ }^{83}$ ) pogreške u očitovanju jedne strane, ako se druga ponašala sukladno načelu savjesnosti i poštenja, ne spriječava nastanak ugovora. Po toj teoriji, ugovor se sklapa suglasnošću očitovanja, odnosno izjava ili poruka, a ne suglasnošću volja. Ugovor se po ovom sistemu zaključuje suglasnošću izjava, a ne suglasnošću volja. ${ }^{84}$ Ovom teorijom se žele zaštititi interesi suugovaratelja, a nedostaci u očitovanju volje se u načelu ne uvažavaju. ${ }^{85}$ Teorija očitovanja odgovara na prvi pogled terminološkom pojmu „objektivne teorije“ izražavanja volje za sklapanjem ugovora kako je nazivaju američki autori, a kako će, također, biti prikazano nešto kasnije.

Međutim, kada se bolje sagledaju obje teorije kako su shvaćene u europskom pravnom krugu, vidjet će se da one ipak odudaraju od američke osnovne polazne postavke. Najbolji pokazatelj toga jest stav da pravni sustavi germanskog kruga zemalja prihvaćaju teoriju očitovanja pri čemu se u taj krug ubraja njemačko, švicarsko i austrijsko pravo (par. 116. BgB-a ${ }^{86}$, par. 861. ABGB-a; čl. 1. OR-a). ${ }^{87}$ Međutim, i kod teorije očitovanja prema tim istim shvaćanjima treba pronaći pravu volju, ${ }^{88}$ a ne samo tumačiti je u doslovnom smislu prema danom očitovanju. Ugovore, dakle i volju ugovornih strana treba tumačiti u dobroj vjeri uzimajući u obzir poslovne običaje. To je temeljno načelo njemačkog prava. ${ }^{89}$ Dapače, isti autor ubraja u sustave koji su

\footnotetext{
${ }^{81}$ U ugovorima važi pravilo da se poštuje prvenstveno namjera ugovornih strana, a tek potom sadržaj njihovih riječi. (Pri tumačenju ugovora treba više voditi računa o onome što su stranke htjele, nego o riječima kojima su to izrazile) - Papinianus - prema Stojčević, D. i Romac, A.: Dicta et Regulae Iuris, (latinska pravna pravila, izreke i definicije sa prevodom i objašnjenjima), drugo dopunjeno izdanje, Savremena administracija, Beograd, 1971., str. 182.

${ }^{82}$ Ovu teoriju nikako ne valja zamjenjivati s teorijom očitovanja glede prijema poruka kod sklapanja ugovora.

${ }^{83}$ Ovaj termin koristi se u Komentaru Zakona o obligacionim odnosima, I knjiga, drugo izdanje, Blagojević, B. (ur) i Krulj, V. (ur), Savremena administracija, Beograd, 1983., str. 106.

${ }^{84}$ Ibid.

${ }^{85}$ Tako Gorenc, V. et. al.; Gorenc, V. (ur.): Komentar Zakona o obveznim odnosima, Narodne novine, Zagreb, 2014., str. 365.

${ }^{86}$ Članak 116. njemačkog Građanskog zakonika (BGB) (Građanski zakonik u verziji proglašenoj 2.1.2002. Bundesgestzblatt I, str. 3719. - "Bürgerliches Gesetzbuch in der Fassung der Bekanntmachung vom 2. Januar 2002. (BGB1. I S. 42, 2909; 2003 I S. 738), das zuletzt durch Artikel 1 des Gesetzes vom 20. Juli 2017. (BGBl. I S. 2787) geändert worden ist")" - Mentalna rezervacija - Izjava volje ne smatra se nevaljanom na osnovi same činjenice što je osoba koja ju je dala imala mentalnu rezervaciju prema kojoj ne želi dati danu izjavu. Izjava je nevaljana ako se daje osobi koja zna za tu rezervaciju.

(\$116 Geheimer Vorbehalt - Eine Willenserklärung ist nicht deshalb nichtig, weil sich der Erklärende insgeheim vorbehält, das Erklärte nicht zu wollen. Die Erklärung ist nichtig, wenn sie einem anderen gegenüber abzugeben ist und dieser den Vorbehalt kennt.)

${ }^{87}$ Tako Gorenc, V. et. al.; Gorenc, V. (ur.): Komentar Zakona o obveznim odnosima, Narodne novine, Zagreb, 2014., str. 365.

${ }^{88}$ Članak 157. BGB-a.

${ }^{89}$ Tako Gorenc, V. et. al.; Gorenc, V. (ur.): Komentar Zakona o obveznim odnosima, Narodne novine, Zagreb, 2014., str. 365 .
} 
prihvatili teoriju očitovanja i hrvatski sustav zasnovan na ZOO $2005 .{ }^{90},{ }^{91}$ te bi analogno tome zaključku u taj sustav ulazilo i bosanskohercegovačko pravo, s obzirom na to da između hrvatskog ZOO-a iz 2005. i jugoslavenskog ZOO-a iz $1978^{92}$. nema u ovom dijelu bitnih razlika. Iako je ovakvo kategoriziranje hrvatskog obveznog prava s ove pozicije barem problematično s obzirom na odredbu čl. 249. ZOO-a 2005. ${ }^{93}$ koji govori isključivo o sadržaju volje, a ne sadržaju izjave volje, te temeljem čl. 247. koji nosi naziv SUGLASNOST VOLJA - „Kad je ugovor sklopljen“- određuje da je ugovor sklopljen kad su se ugovorne strane suglasile o bitnim sastojcima ugovora. Naime, naziv članka njegov je sastavni dio pa je jasno kada se uzme u obzir i naslov članka da je ugovor sklopljen kada se ostvarila suglasnost volja ugovornih strana. Zakon ne sadrži odredbu da je ugovor sklopljen kada su se suglasile izjave volja ugovornih strana, kada bi se moglo reći da se prihvaća teorija očitovanja. Sve navedeno važi i za bosanskohercegovačko pravo i ZOO 1978.

Slično tome i Švicarski zakonik o obligacijama ${ }^{94}$ u čl. 1. određuje da je ugovor zaključen onda kada su ugovorne strane uzajamno i suglasno izjavile svoju volju, a naslov članka je I suglasnost volja, a naslov poglavlja - Zaključenje ugovora. ${ }^{95}$ Američki autori ${ }^{96}$ posebno

\footnotetext{
${ }^{90}$ Zakon o obveznim odnosima - Narodne novine br. 35/05, 41/08, 125/11.

${ }^{91}$ Tako Gorenc, V. et. al.; Gorenc, V. (ur.): Komentar Zakona o obveznim odnosima, Narodne novine, Zagreb, 2014., str. 365.

${ }^{92}$ Zakon o obveznim odnosima, (Zakon o obligacionim odnosima) FBiH i RS, Službeni list SFRJ 29/78, 39/85, 45/89, 57/89; Službeni list RBiH 2/92, 13/93, 13/94 ; Službeni glasnik RS 17/93, 3/96, 74/04. U daljnjem tekstu korsiti se samo naziv - skraćenica ZOO 1978.

${ }^{93}$ Izjava volje

Članak 249.

(1) Volja za sklapanje ugovora može se izjaviti riječima, uobičajenim znakovima ili drugim ponašanjem iz kojega se sa sigurnošću može zaključiti o njezinu postojanju, sadržaju i identitetu davatelja izjave.

(2) Volja za sklapanje ugovora može se izjaviti i pomoću različitih komunikacijskih sredstava.

(3) Izjava volje mora biti učinjena slobodno i ozbiljno.

${ }^{94}$ Objavljen u srpskohrvatskom prevodu u knjizi: Švajcarski zakonik o obligacijama, Institut za uporedno pravo, Savremena administracija, Beograd, 1976.

${ }_{95}$ Prema tekstu zakonika iz Švajcarski zakonik o obligacijama, Institut za uporedno pravo, Savremena administracija, Beograd, 1976., str. 13.

${ }^{96}$ Kis, S.: Contracts and Electronic Agents, LLM Theses and Essays., University of Georgia Law, Digital Commons@Georgia Law, Student Works and Organizations, elektroničko izdanje (str. 1-79.), Athens Georgia, 2004., dostupno na http://digitalcommons.law.uga.edu/stu_llm/25, str. 47. (1.8.2014).
} 
naglašavaju odredbu čl. 1369.5 st. $1 .{ }^{97}$ francuskog Građanskog zakonika ${ }^{98}$ prema kojoj je za valjano sklapanje ugovora elektroničkim putem nužno da je primatelj ponude imao mogućnost provjere (pregleda) svih elemenata njegove narudžbe i cijene u cjelini, kao i da je imao mogućnost ispraviti moguće pogreške prije potvrde kojom očituje svoj prihvat ponude te temeljem koje se izvodi zaključak da se radi o primjeru primjene teorije volje, odnosno subjektivnog principa prilikom sklapanja ugovora. ${ }^{99}$ Smatram da se ovdje primjenjuje neprihvatljivo ekstenzivno tumačenje ove norme. Naime, ova norma treba biti kao iznimka tumačena isključivo suženo, a to je da se ona odnosi samo na sklapanje ugovora elektroničkim putem na WEB stranici (click wrap ugovor). ${ }^{100}$ Usprkos tome, nesumnjivo je da u njoj postoji prisustvo elemenata koji bi mogli navesti na zaključak o prihvaćanju teorije volje prilikom sklapanja ugovora, jer u suprotnom slučaju navedeni autori ne bi došli do takvog zaključka.

No, najvažnije pitanje za nas jest je li ZOO iz 1978., kao i navedeni švicarski uzor, prihvatio sistem volje ili sistem izjave. Ako bi se doslovno tumačio podnaslov (Suglasnost volja), onda bi se mogao izvesti zaključak da se ZOO 1978. opredijelio za sistem volje. Obrnuto, formulacija čl. 26. i postojanje i sadržaj čl. 28. govore u prilog sistema izjave. ${ }^{101}$ Većina pravnih sistema daje u ovoj domeni prednost sistemu izjave, ali ne i apsolutnu prevagu. Tu spadaju i pravni

\footnotetext{
${ }^{97}$ Građanski zakonik Francuske (Civil Code) (consolidated version of the Civil Code incorporates all the amendments up to Decree No. 2017-278 of March 2, 2017, relating to the Time Limit for the Declaration of Birth, which was published on March 4, 2017 in the Official Gazette, and entered into force on March 5, 2017. The said 2017-278 of March 2, 2017 introduces amendments to Article 55 under Book I, Title II, Chapter II, Section 1 of the consolidated version.). Izvor konsolidirane verzije Građanskog zakonika je: https://www.legifrance.gouv.fr/affichCode.do?cidTexte=LEGITEXT000006070721\&dateTexte=20130701,

Legifrance website, Directorate of Legal and Administrative Information (DILA)

(prema WIPO - WIPO Lex - France Civil Code (consolidated version of March 2, 2017)

http://www.wipo.int/wipolex/en/details.jsp?id=17359 (18.4.2018.), tekst se daje prema navedenom izvoru (u prijevodu na hrvatski)

Članak 1369-5

(1) Kako bi ugovor bio valjano sklopljen, primatelj ponude morao je imati mogućnost provjeriti podatke o svojoj narudžbi i ukupnoj cijeni te ispraviti eventualne pogreške prije nego što je dao svoj prihvat.

(2) Autor ponude bez odgode i elektroničkim putem potvrđuje primitak narudžbe koja mu je upućena na taj način. Narudžba, potvrda o prihvatu ponude i potvrda o primitku smatrat će se zaprimljenim kada im strane, kojima su iste upućene, mogu pristupiti.

${ }^{98}$ Ibid.

${ }^{99}$ Kis, S.: Contracts and Electronic Agents, LLM Theses and Essays., University of Georgia Law, Digital Commons@Georgia Law, Student Works and Organizations, elektroničko izdanje (str. 1-79.), Athens Georgia, 2004., dostupno na http://digitalcommons.law.uga.edu/stu_llm/25, str. 53. (1.8.2014.) - Existing French law obviously deprives of effectiveness contracts concluded through electronic agents if it allows the party-user to claim he has not had the opportunity to review the terms of the agreement.

${ }^{100}$ Takva regulativa je prihvaćena i u SAD-u, gdje se također smatra da je je za click wrap ugovor nužno da ga pristupatelj ugovoru mora moći cijelog pročitati - vidjeti detaljno Rainey, „Chip“ J., u knjizi ONline Contract Formation, Kinsella N. S. (ur), i Simpson, F. A. (ur), prvo izdanje, Oceana publications, Inc. New York, 2004. 324-332.

${ }^{101}$ Komentar Zakona o obligacionim odnosima, I knjiga, drugo izdanje, Blagojević, B. (ur) i Krulj, V. (ur), Savremena administracija, Beograd, 1983., str. 106.
} 
sistemi (austrijski, švicarski) koji su tradicionalno imali značajan utjecaj na jugoslavensko pravo, a time i na ZOO 1978. Treba stoga smatrati da i naš ZOO 1978. daje prednost sistemu izjave, ali da od njega odstupa kad njegova primjena vodi neadekvatnim rezultatima ${ }^{102}$ Očito je dakle da je prilično teško razlikovati ove dvije teorije u praksi kada svaka biva korigirana $u$ primjeni u slučajevima kad njezina primjena vodi neadekvatnim rezultatima.

No, bez obzira na navedeno kuda i kako kategorizirali hrvatsko i bosanskohercegovačko pravo, ako je to uopće moguće i/ili potrebno, glede ove tematike sigurno jest da nijedno od njih, pa posljedično i druga kontinentalna prava koja i nominalno prihvaćaju teoriju očitovanja, ne prihvaćaju američku objektivnu teoriju na jednaki način glede izražavanja volje za sklapanje ugovora.

Objektivna teorija manifestira se u Zbirci propisa (drugoj) o ugovorima (Restatement (Second) of Contracts) ${ }^{103}$ u paragrafu 21. naziva Intention to be legally bound (hrv. namjera za pravnim obvezivanjem):

Niti stvarna niti očita namjera (volja ugovornih strana) da obećanje bude pravno obvezujuće nije bitna za sklapanje ugovora, ali (je bitna) manifestacija (izjava) o namjeri da obećanje neće utjecati na pravni odnos i tako može spriječiti sklapanje ugovora. ${ }^{104}$

Kako ovakvih odredbi nema u kontinentalnim pravima, pitanje je može li se uopće kontinentalno shvaćanje teorije očitovanja poistovjetiti s američkom objektivnom teorijom očitovanja za sklapanje ugovora iako bi zapravo to trebala biti ista teorija.

\footnotetext{
${ }^{102}$ Komentar Zakona o obligacionim odnosima, I knjiga, drugo izdanje, Blagojević, B. (ur) i Krulj, V. (ur), Savremena administracija, Beograd, 1983., str. 106. Međutim, nemoguće se oteti dojmu, pa i zaključku, da je ovdje primijenjen argumentum ad personam, a ne argumentum ad rem ili da je barem problematična upotreba argumentum ad rem pri postavljanju ovakve teze ili zaključka.

103 „Restatements“ su visoko cijenjeni „,destilati“ common lawa. Njih priprema Američki pravni institut American Law Institute (ALI), prestižna organizacija koja obuhvaća suce, profesore prava i odvjetnike. Cilj ALIja je ekstrahirati "crna slova zakona" iz predmeta te ukazati na trendove u common lawu, a povremeno preporučiti što bi zakonska pravila trebala biti. U biti, oni pretvaraju (,restate ${ }^{\text {") }}$ postojeći common law u niz načela i pravila. „Restatements“ pokrivaju široke teme, kao što su ugovori ili imovina. Posloženi su u poglavlja, podnaslove, te u članke. Članci sadrže jasno i precizno navedeno zakonsko pravilo, komentare kojima se pravilo objašnjuje, hipotetske primjere, objašnjenje svrhe, kao i iznimke od pravila. „Restatements“ nisu primarni izvor prava. Međutim, zbog prestiža ALI-ja te mukotrpnog procesa njihove izrade, mnogi ih sudovi smatraju uvjerljivim izvorom prava. Najviše se citiraju „restatements“ iz odštetnog i ugovornog prava. Oni su skup pravila koja služe sucima i odvjetnicima kao izvori općih principa prava. Sada postoje četiri serije tih pravila koja je sva izdao i objavio ALI. Web stranica ALI-ja sadrži informacije u vezi „Restatement“‘- projekata, članstva u ALI-ju, povijesti i institucionalnim procesima. - prema Harward Law School - Knjižnica, dostupno na http://guides.library.harvard.edu/content.php?pid=103327\&sid=1036651, (5.2.2015.).

${ }^{104} \mathrm{U}$ engleskom izvorniku: Neither real nor apparent intention that a promise be legally binding is essential to the formation of a contract, but a manifestation of intention that a promise shall not affect legal relations may prevent the formation of a contract. Nema prijevoda Restatementa na hrvatski jezik, ovdje je prijevod autorov.
} 
Dapače, izgleda da američko subjektivno shvaćanje očitovanja ne obuhvaća samo kontinentalnu teoriju volje (nedvojbeno), već i kontinentalnu teoriju očitovanja (kada ne iznosi jednaki stav kao i subjektivna teorija, odnosno kada je teorija očitovanja nejasno formulirana u definiciji - kao što je slučaj kod ZOO 1978. - te kada ima i suviše izuzetaka da zapravo izuzeci postaju pravilo ili ih je naprsto veći broj, jer je tada distinkcija između njih, iz perspektive subjektivne teorije, suviše mala i zapravo je upitna). Naime, prema takvom razmišljanju obje navedene teorije, iz položaja subjektivne teorije, bile bi de facto teorija volje, bilo teorija volje, bilo teorija očitovanja (koja nije potpuno sukladna subjektivnoj teoriji) koja ima svoje značajne izuzetke $^{105}$ pa je stoga zapravo, in fine, praktično svejedno koja se primjenjuje. Stoga je za zaključiti da teorija očitovanja ili izjave ipak polazno odgovara objektivnoj teoriji kako je shvaćaju američki autori, s tim da je objektivna teorija samo dosljednije provedena kroz (američku) legislativu. No, činjenica je da polazne pretpostavke, kako je iznesena iz citiranog Restatementa par. 21 nema u kontinentalinim pravnim sustavima. Jednako tako Restatementi dosljedno govore o manifestaciji volje, a ne njezinom sadržaju. Tako par. 20. kada govori o učincima nesporazuma (disenza) određuje There is no manifestation of mutal assent to an exchange if the... (Nema manifestacije zajedničke suglasnosti ako...), za razliku od primjerice ZOO 1978. koji u čl. 63. ${ }^{106}$ govori neutralno o vjerovanju stranaka, a ne o nesukladnosti njihovih izjava volje iako nesumnjivo mora postojati zapravo (i) nesukladnost njihovih izjava volja.

\section{Američki pristup i objektivna teorija izražavanja suglasnosti (prihvata) za sklapanje ugovora}

Prema Zbirci propisa (drugoj) o ugovorima (Restatement (Second) of Contracts), ${ }^{107}$ ugovor je obećanje ili skup obećanja. ${ }^{108}$ To obećanje izražava ugovorna strana, obično riječima, premda ono može biti vidljivo i iz njezina ponašanja. ${ }^{109}$ Da bi se sklopio ugovor, nije nužan

\footnotetext{
105 Vidi Tako Gorenc, V. et. al.; Gorenc, V. (ur.): Komentar Zakona o obveznim odnosima, Narodne novine, Zagreb, 2014., str. 366.

${ }^{106} \mathrm{Kad}$ strane vjeruju da su suglasne, a u stvari među njima postoji nesporazum o prirodi ugovora ili o osnovi ili o predmetu obveze, ugovor ne nastaje.

107 RESTATEMENT (SECOND) OF CONTRACTS (1981)., SAD, tekst dostupan na https://luatcanhtranhvabaovenguoitieudung.wordpress.com/2011/06/08/the-us-restatement-second-of-contractsof-1981/, te na https://www.nylitigationfirm.com/files/restat.pdf, (10.1.2016.).

${ }^{108}$ Chapter 1 - Meaning of terms $\S 1$. CONTRACT DEFINED: A contract is a promise or a set of promises for the breach of which the law gives a remedy, or the performance of which the law in some way recognizes as a duty. ${ }^{109} \S$ Chapter 1 - Meaning of terms $\S 2$. PROMISE; PROMISOR; PROMISEE...

(1) A promise is a manifestation of intention to act or refrain from acting in a specified way, so made as to justify a promisee in understanding that a commitment has been made.

(2) The person manifesting the intention is the promisor.
} 
subjektivni pristanak stranke, već manifestacija interesa. ${ }^{110}$ Da bi se stvorila obveza, potrebna su dva uvjeta. Prvo, mora postojati obećanje i drugo, manifestacija suglasnosti svake strane mora se referirati na manifestaciju suglasnosti druge. ${ }^{111}$ Kako je vidljivo iz čl. 21. ovih pravila, (subjektivna) volja stranaka nije bitna nego manifestacije volje. Kako je volja subjektivni pojam, a manifestacija te volje zapravo objektivni čin, na bazi ove podjele smatra se da američko pravo na objektivan način utvrđuje nastanak ili nenastanak ugovora zanemarujući, u pravilu, subjektivni faktor, tj. subjektivnu volju ili namjeru. Stoga se američki teorijski i legislativni sustav sklapanja ugovora naziva objektivnim sustavom.

U pravilu se sama volja kao subjektivna kategorija sadržajno poklapa s manifestacijom volje, no to ne mora uvijek biti slučaj te su granična područja ona koja izazivaju potencijalne pravne nedoumice. ${ }^{112}$ Ovdje se neće koncentrirati na opće nedoumice, već samo na nedoumice koje mogu nastati u okvirima elektroničkog načina komuniciranja i sklapanja ugovora. Kod

(3) The person to whom the manifestation is addressed is the promisee...

${ }^{110}$ Prema Kis, S.: Contracts and Electronic Agents, LLM Theses and Essays., University of Georgia Law, Digital Commons@Georgia Law, Student Works and Organizations, elektroničko izdanje (str. 1-79.), Athens Georgia, 2004., dostupno na http://digitalcommons.law.uga.edu/stu_llm/25, str. 44. (1.8.2014.).

111 RESTATEMENT (SECOND) OF CONTRACTS (1981)., SAD, CHAPTER 3 - FORMATION OF CONTRACTS-MUTUAL ASSENT - §21. INTENTION TO BE LEGALLY BOUND

Neither real nor apparent intention that a promise be legally binding is essential to the formation of a contract, but a manifestation of intention that a promise shall not affect legal relations may prevent the formation of a contract. U komentaru (RESTATEMENT (SECOND) OF CONTRACTS (1981)., SAD, tekst dostupan na https://luatcanhtranhvabaovenguoitieudung.wordpress.com/2011/06/08/the-us-restatement-second-of-contractsof-1981/ (1.11.2016.) unutar same ove zbirke propisa u odnosu na §21 stoji:

b. Agreement not to be legally bound. Parties to what would otherwise be a bargain and a contract sometimes agree that their legal relations are not to be affected. In the absence of any invalidating cause, such a term is respected by the law like any other term, but such an agreement may present difficult questions of interpretation: it may mean that no bargain has been reached, or that a particular manifestation of intention is not a promise; it may reserve a power to revoke or terminate a promise under certain circumstances but not others. In a written document prepared by one party it may raise a question of misrepresentation or mistake or overreaching; to avoid such questions it may be read against the party who prepared it.

The parties to such an agreement may intend to deny legal effect to their subsequent acts. But where a bargain has been fully or partly performed on one side, a failure to perform on the other side may result in unjust enrichment, and the term may then be unenforceable as a provision for a penalty or forfeiture...

${ }^{112}$ Značenje same manifestacije volje, a ne sadržaja volje, vidljivo je i iz paragrafa 20. koji govori o disenzu, a govori upravo o manifestaciji volje, a ne sadržaju volje, te isto tako štiti na potrebnoj razini savjesnog partnera, odnosno savjesnost ugovornih strana.

UCITA - CHAPTER 3 - FORMATION OF CONTRACTS-MUTUAL ASSENT §20. EFFECT OF MISUNDERSTANDING

(1) There is no manifestation of mutual assent to an exchange if the parties attach materially different meanings to their manifestations and (a) neither party knows or has reason to know the meaning attached by the other; or

(b) Each party knows or each party has reason to know the meaning attached by the other.

(2) The manifestations of the parties are operative in accordance with the meaning attached to them by one of the parties if (a) that party does not know of any different meaning attached by the other, and the other knows the meaning attached by the first party; or (b) that party has no reason to know of any different meaning attached by the other, and the other has reason to know the meaning attached by the first party. 
korištenja elektroničkog agenta za provedbu transakcije, korisnik ili vlasnik elektroničkog robota nije svjestan postojanja sporazuma sve dok njegov agent ne sklopi pravni posao. ${ }^{113}$

Usprkos tome treba smatrati da je korisnik elektroničkog agenta manifestirao suglasnost na sklapanje ugovora koji je sklopio elektronički agent, a ta je suglasnost manifestirana činjenicom što je korisnik odlučio koristiti elektroničkog agenta programiravši ga na sklapanje određenih ugovora. ${ }^{114}$

Iznimno je važno voditi računa o tome da opće pravilo - da se na ponudu učinjenu bilo kojim oblikom komunikacije može odgovoriti isto tako bilo kojim razumnim oblikom komunikacije ${ }^{115}$ - kod elektroničkog sklapanja ugovora biva radikalno ograničeno. Naime, ponude dane zatvorenim EDI-jem i elektroničkim agentom podrazumijevaju i dopuštaju odgovor samo unutar tog pravno-komunikacijskog sustava, jer bi u suprotnom slučaju cijeli sustav gubio svaki smisao i značenje. Tako, primjerice, kod dva najčešća formularna ugovora koji se sklapaju na WEB stranicama, click wrap $^{116}$ i browse wrap $^{117}$ ugovorima, između posjetitelja stranice i elektroničkog agenta, odnosno programiranog računala koje odgovara na znakove posjetitelja stranice i pristupatelja ugovoru, nije moguće sklopiti drugačije nego li davanjem na stranici predviđenih elektroničkih znakova koji se čine pokretom mišem. ${ }^{118}$

Sukladno tome, u ova dva slučaja moglo bi se govoriti o dva tipa forme prihvata:

a/ Zahtijevana, odnosno tražena forma (required form) ${ }^{119}$ - prema kojoj je ponuditelj gospodar svoje ponude. Ponuda može izričito sadržavati uvjete forme i načine oblika prihvata

\footnotetext{
${ }^{113}$ Kis, S.: Contracts and Electronic Agents, LLM Theses and Essays., University of Georgia Law, Digital Commons@Georgia Law, Student Works and Organizations, elektroničko izdanje (str. 1-79.), Athens Georgia, 2004., dostupno na http://digitalcommons.law.uga.edu/stu_llm/25, str. 45. (1.8.2014.).

114 Ibid.

115 UCITA - CHAPTER 3 - FORMATION OF CONTRACTS-MUTUAL ASSENT §30. FORM OF ACCEPTANCE - INVITED (1) An offer may invite or require acceptance to be made by an affirmative answer in words, or by performing or refraining from performing a specified act, or may empower the offeree to make a selection of terms in his acceptance. (2) Unless otherwise indicated by the language or the circumstances, an offer invites acceptance in any manner and by any medium reasonable in the circumstances.

${ }^{116} \mathrm{O}$ click wrap ugovorima vidjeti detaljno kod „Chip“ Rainey, J. u knjizi Online Contract Formation, Kinsella, N. S. (ur) i Simpson, F. A., (ur.) Oceana Publication, Inc, Dobbs Ferry, New York, SAD, prvo izdanje, 2004., str. 328.

117 Ibid, str. 329-332.

118 O pravnom značenju pokreta mišem na web stranici, uz argumentaciju da se radi o znaku - vidjeti kod Matić, T.: Osnove prava elektroničke trgovine, MEP Consult, Zagreb, 2008., str. 94- 96.

119 Vidjeti UCITA - CHAPTER 3 - FORMATION OF CONTRACTS-MUTUAL ASSENT §30. FORM OF ACCEPTANCE - INVITED (1) An offer may invite or require acceptance to be made by an affirmative answer in words, or by performing or refraining from performing a specified act, or may empower the offeree to make a selection of terms in his acceptance. (2) Unless otherwise indicated by the language or the circumstances, an offer invites acceptance in any manner and by any medium reasonable in the circumstances.
} 
ponude, odnosno manifestacije volje prihvata. U tom slučaju zahtijevana forma postaje konstitutivan način za sklapanje ugovora, a prihvat proizvodi pravni učinak samo ako je dan u toj formi. Prihvat učinjen u drugoj formi predstavlja zapravo novu ponudu. Ponuda učinjena elektroničkim agentom te zatvorenim EDI-jem trebala bi se smatrati zahtijevanom ponudom glede forme očitovanja prihvata. U sustavu Zakona o obveznim odnosima 1978. ovdje se zapravo radi o ugovorenoj formi ugovora iz čl. 69. ZOO-a prema kojem se ugovorne strane mogu sporazumjeti da posebna forma bude uvjet pravovaljanosti njihova ugovora. Usprkos tome što zatvoreni EDI i elektronički agent zapravo ne čine formu (forma je elektronička) nego način sklapanja ugovora, smatram da je ovo pravilo nužno tumačiti na jednaki način i u odnosu na način sklapanja ugovora.

b/ Pozvana forma (inivited form) ${ }^{120}$ - prema kojoj ponuditelj zapravo očekuje da prihvat bude dan u određenoj formi, odnosno na određeni način, no ne ograničava mogućnost davanja ili manifestiranja prihvata na neki drugi način, odnosno formu. U tom slučaju očito je da pozvana forma nije konstitutivni element za nastanak ugovora. U ovom slučaju radi se o situaciji koju zapravo regulira čl. 69. st. 3. ZOO-a 1978. prema kojem, ako su ugovorne strane predvidjele određenu formu samo da osiguraju dokaz svojeg ugovora ili da postignu što drugo, ugovor je sklopljen kad je postignuta suglasnost o njegovu sadržaju.

Kod elektroničkog agenta nema izvora regulacije pa je odgovor moguće jedino konstruirati temeljem pravne prirode ovog načina komunikacije. S obzirom da se radi o elektroničkom agentu koji daje ponudu, prihvat bi trebao biti upućen također samo njemu, posebno ako se ne zna u čije ime i za čiji račun nastupa. No, i u slučaju da se zna za čije ime i čiji račun nastupa, moglo bi se tumačiti da je prihvat moguće dati i na drugi način, a ne samo komunikacijom s elektroničkim agentom. No, s obzirom na to da je vlasnik, odnosno korisnik elektroničkog agenta izabrao takav način komuniciranja, za pretpostaviti je da je htio da se ugovor sklopi isključivo putem elektroničkog agenta, te da se svi drugi oblici prihvata na ponudu učinjenu putem elektroničkog agenta mogu smatrati samo novim ponudama, a ne prihvatom ponude. Stoga bi trebalo pretpostaviti da korištenje elektroničkog agenta pretpostavlja i traženu ili zahtijevanu formu odgovora ili prihvata u elektroničkom obliku koji može čitati elektronički agent putem kojeg je dana ponuda jer takvo pravilo postavlja pravna i faktična priroda tog oblika elektroničke komunikacije.

${ }^{120}$ Ibid. 


\section{Europski kontinentalni pristup i subjektivna teorija izražavanja suglasnosti (prihvata) za sklapanje ugovora}

Kontinentalno ugovorno pravo temelji se na slobodi i slobodnoj volji pojedinca. Kada američki autori procjenjuju kontinentalne pravne sustave izražavanja suglasnosti, odnosno prihvata za sklapanje ugovora, obično navode da ugovorna obveza nastaje samo ako obje ugovorne strane to žele. Pravni sustavi ne razlikuju volju od manifestacije volje, pa stoga dolazi do „nadmoći“ unutarnje (stvarne) volje. Naime, kod presuđivanja je li stranka namjeravala obvezati se ili ne, sudovi će morati razmatrati i unutarnju volju, a ne samo iskazanu (vanjsku) manifestaciju volje. ${ }^{121}$

ZOO 1978. u čl. 26. koji regulira kad je ugovor sklopljen navodi da je ugovor sklopljen kad su se ugovorne strane suglasile o bitnim sastojcima ugovora, ali naslov odsjeka je sklapanje ugovora, podnaslov je 1. - Suglasnost volja. Dakle, u cjelini kada se razmotri tekst članka i naslov i podnaslov članka ugovor je sklopljen kad su se suglasile volje ugovornih strana. Isto proizlazi i iz čl. 28. ZOO 1978. koji nosi naziv Izjava volje - volja za sklapanje ugovora može se izjaviti riječima, uobičajenim znacima ili drugim ponašanjem iz kojeg se sa sigurnošću može zaključiti o njezinom postojanju. Izjava volje mora biti učinjena slobodno i ozbiljno. Dakle, i prihvat i ponuda su izjave volje, dakle baziraju se na isključivo subjektivnom elementu kod bilo koje ugovorne strane.

Općeprihvaćeni teorijski pristup identičan je onom koji proizlazi iz ZOO-a 1978., pa tako npr. Martin Vedriš i Petar Klarić u Građanskom pravu ${ }^{122}$ govore da Zakon o obveznim odnosima pravilno razlikuje oblik očitovanja volje (čl. 28. st. 1.) od oblika pravnih poslova, odnosno od oblika ugovora te da ugovor nastaje očitovanjem volje dviju strana, pa je tada samo po sebi razumljivo da se ta dva očitovanja volje moraju na neki način sastati, spojiti, jer samo onda kad se sjedine stvaraju cjelinu koja se zove ugovor. Osim toga, potpuno je logično da obje strane moraju znati za svoja uzajamna očitovanja. Prema tome, strana koja hoće sklopiti ugovor mora svoju volju na neki način uputiti onoj strani s kojom hoće sklopiti ugovor. Kako je vidljivo, dominantno se govori o suglasnosti volja za sklapanjem ugovora, dakle o suglasnosti između dvaju subjektivnih stavova. Ne govori se o manifestaciji suglasnosti za sklapanje ugovora kao

\footnotetext{
${ }^{121}$ Kis, S.: Contracts and Electronic Agents, LLM Theses and Essays., University of Georgia Law, Digital Commons@Georgia Law, Student Works and Organizations, elektroničko izdanje (str. 1-79.), Athens Georgia, 2004., dostupno na http://digitalcommons.law.uga.edu/stu_llm/25, str. 47. (1.8.2014.).

${ }^{122}$ Vedriš, M. i Klarić, P.: Građansko pravo, Narodne novine, Zagreb, 2003., str. 121.
} 
u američkom pravu, već o suglasnosti volja za sklapanjem ugovora, a niti postoji distinkcija ta dva pojma. Naime, nema termina „manifestacije suglasnosti“ kao distingvirajućeg prema korištenom terminu „očitovanje volje,“ iako bi se takav termin mogao koristiti, polazeći od objektivne teorije, a koristeći jezik kontinentalnog pravnog sustava, o sadržaju očitovanja volje u odnosu na volju. Koristi se samo termin očitovanje ili izjava volje koji su dominanto usmjereni na stvarnu volju. Možda bi se moglo reći da je američka teorija formalnija jer govori i koncentrira se samo na značenje same manifestacije, ne ulazeći u njezin stvarni sadržaj, a što bi trebalo biti obilježje subjektivne teorije.

Međutim, već je ranijom analizom pokazano da je upitna razlika između ovih dviju teorija u odnosu na europske sustave obveznog prava. Kako je ranije navedeno i prikazano, američka objektivna teorija predstavlja samo krajnost teorije izjave, a europska praktična rješenja se kreću u području od teorije izjave do teorije volje.

Međutim, usprkos ovim razlikama, u tradicionalnom pravnom okružju ove dvije teorije u praktičnom svijetu sadrže minimalne razlike i praktički se ne razlikuju u primjeni. No, u virtualnom okružju mogu uzrokovati veliku razliku.

Naime, virtualni svijet računala u kojem komuniciraju računala, iako su programirana po ljudima, ne poznaje volju u subjektivnom smislu, već samo u objektivnom smislu kroz njezino izražavanje, odnosno manifestaciju. Računalo ne može izraziti subjektivnu volju jer je nema; ono uvijek objektivno izražava moguću subjektivnu volju svojeg korisnika ili vlasnika.

Stoga bi bosanskohercegovački, hrvatski i općenito svaki kontinentalni pravni sustav ugovornog prava morao ozbiljno razmotriti mogućnost postavljanja pravila o punoj objektivnosti volje u računalnim transakcijama, odnosno komunikacijama u kojim ne sudjeluju neposredno ljudi. Ako bi nešto takvo bilo prihvatljivo, dopuna čl. 26.ZOO-a 1978. kao st. 2. trebala bi otprilike glasiti:

Ugovorna volja može se izraziti putem računala, automatiziranim računalnim sustavima bez sudjelovanja čovjeka. Volja ugovorne strane izražena automatiziranim računalnim putem bez neposrednog sudjelovanja čovjeka prosuđuje se isključivo prema njezinu izrečenom, odnosno elektronički prenesenom sadržaju.

Ovakvim pravilom prvenstveno bi se eliminirao utjecaj svjesnog nesklada između volje i očitovanja, dok bi se nesvjesni nesklad koji nastaje zbog prijetnje (uključivši silu), zablude i 
prijevare i dalje mogao primijeniti, s obzirom na to da se radi o neskladu koji nastaje u fazi programiranja elektroničkog agenta.

Izričito stipuliranje ovakvog pravila u legislativi ne bi škodilo niti u objektivnom sustavu SADa radi jasnijeg utvrđenja posebnosti automatiziranih računalnih transakcija. ${ }^{123}$

Tako teoretičari u SAD-u smatraju djelovanje i očitovanje elektroničkog agenta za sklapanjem ugovora „manifestacijom namjere za postizanje suglasnosti“ ${ }^{124}$ te se u tim slučajevima primjenjuje objektivna teorija o očitovanju volje za sklapanjem ugovora ${ }^{125}$ a što je kompatibilno s naprijed predloženim.

Ugovor sklopljen putem elektroničkog agenta obvezuje njegove korisnike bez obzira jesu li oni kao takvi imali priliku pročitati ugovor prije njegova sklapanja. Ovo stoga što je elektronički agent samo način sklapanja ugovora i zato što kroz njega djeluje korisnik neposredno u svoje ime i za svoj račun. Pregled ili intervencija ljudskog faktora, koji koristi u svojem poslovanju elektroničkog agenta, nepotrebni su. Korištenjem sustava koji nastupa u njihovo ime i za njihov račun, ugovorna strana očitovala je potrebnu ljudsku, subjektivnu, volju da poduzme one radnje koje je sustav poduzimao kako je programiran. ${ }^{126}$

Volja za sklapanjem ugovora mora se stvoriti i iskazati prije ili istodobno s razmjenom pravno relevantnih poruka. Ako se netko koristi elektroničkim agentom, u kojem trenutku možemo sagledati unutarnje stanje volje ili uma? To bi, prema navedenom pravilu, trebalo biti moguće samo prije sklapanja određenog ugovora, odnosno prije ,puštanja robota ili elektroničkog agenta u pogon.“ No, takva „volja“ elektroničkog agenta zapravo može biti samo pretpostavljena volja njegova korisnika ili vlasnika za sklapanje tih i takvih ugovora. Naime, korisnik elektroničkog agenta ne može znati da je elektronički agent sklopio ugovor prije nego li je ugovor sklopljen. Stoga, zapravo ljudski kontrolor ne može dati ili ne dati svoj pristanak na ugovor koji se sklapa putem elektroničkog agenta prije ili istodobno s pregovorima ili

\footnotetext{
${ }^{123}$ Subjektivna teorija doživjela je brojne kritike pa se često navodi da danas argument subjektivne volje ima brojne iznimke, često da bi se zaštitila slabija strana u transakcijama, posebno potrošačkim - prema Kis. S.: Contracts and Electronic Agents, LLM Theses and Essays., University of Georgia Law, Digital Commons@Georgia Law, Student Works and Organizations, elektroničko izdanje (str. 1-79.), Athens Georgia, 2004., dostupno na http://digitalcommons.law.uga.edu/stu_llm/25, str. 47., (1.8.2014.).

${ }^{124}$ Manifestation of intention to agree.

${ }^{125}$ Chopra, S. i White, L.: Artificial Agents and the Contracting Problem: A Solution Via an Agency Analysis, University of Illinois Journal of Law Technology \& Policy, br. 2, Chicago, 2009. str. 363-403., str. 374., dostupno na http://ssrn.com/abstract=1589564, (4.2.2015.).

${ }^{126}$ Tako i Kilian, W., u knjizi Boss, H. A., i Kilian, W.: The United Nations Convention on the Use of Electronic Communications in International Contracts, Wolters Kulwer, Austin i dr., 2008., str. 187.
} 
razmjenom pravno relevantnih poruka nego tek naknadno, kada je ugovor već sklopljen. Tako na strani osobe koja sklapa ugovor putem elektroničkog agenta imamo uvodno pretpostavljenu volju za sklapanjem tog ugovora te, naknadno, nakon sklapanja ugovora potencijalnu pravu volju za sklapanje tog ugovora. Imali bismo dakle potencijalni sukob pretpostavljene i stvarne volje, a kada se to prevede na opise prikazanih teorija o sklapanju ugovora, imali bismo sukob objektivne teorije sa subjektivnom. Davanje eventualne prednosti subjektivnoj teoriji, odnosno stvarnoj (naknadnoj) volji nad objektivnim sadržajem iznesenim u elektroničkoj poruci (presumiranoj prethodnoj volji) elektroničkog agenta može stvoriti pravnu nesigurnost $u$ pravnom prometu koji se ostvaruje elektroničkim agentima i zasigurno ne pridonosi razvoju elektroničkog poslovanja.

\section{Zaključci}

Ugovor sklopljen korištenjem elektroničkog agenta valjan je. Ponuda za sklapanje ugovora učinjena elektroničkim agentom može biti prihvaćena samo na način kako to određuje elektronički agent - u pravilu samo određenim načinom (elektroničke) komunikacije.

Korisnik elektroničkog agenta očitovao je - izrazio je presumiranu volju za sklapanjem ugovora putem elektroničkog agenta samim njegovim korištenjem i puštanjem u rad. Ova volja po svojem značenju izjednačena je s voljom za sklapanjem ugovora koja se daje očitovanjem prije upoznavanja svih elemenata ugovora iz čl. 28. st. 1. ZOO-a 1978. ${ }^{127}$

Ovako izražena volja smatra se učinjenom ozbiljno te slobodno, ${ }^{128}$ a presumirana volja ne može se svojevoljnom subjektivnom dispozicijom izmijeniti, te korisnik elektroničkog agenta snosi rizik rada elektroničkog agenta.

Presumira se da je korisnik elektroničkog agenta prethodno upoznat sa sadržajem svih i svakog ugovora, koje sklapa putem elektroničkog agenta - što proizlazi iz činjenice njegovog programiranja te određivanja opsega njegovih programskih mogućnosti.

\footnotetext{
${ }^{127}$ Volja za zaključenje ugovora može se izjaviti riječima, uobičajenim znacima ili drugim ponašanjem iz koga se sa sigurnošću može zaključiti o njenom postojanju.

${ }^{128}$ Čl. 28. st. 2. ZOO-a. 1978. Izjava volje mora biti učinjena slobodno i ozbiljno.
} 
Korisnik elektroničkog agenta može se pozivati na subjektivni element, odnosno samo na nesvjesni nesklad koji nastaje zbog prijetnje (uključivši silu), ${ }^{129}$ zablude $^{130}$ i prijevare ${ }^{131}$ kod ugovora sklopljenih putem elektroničkog agenta, ali samo kada se ove mane volje dogode u fazi pripremanja elektroničkog agenta za rad, odnosno prije nego li je pušten u rad i u odnosu na nesavjesnog sukontrahenta. Ove mane volje ne mogu se primijeniti u odnosu na samog elektroničkog agenta u funkciji, a po samoj prirodi stvari. Svjesni nesklad, prividni ugovor, ${ }^{132}$ simulacija, neozbiljna izjava te mentalna rezervacija ${ }^{133}$ ne bi trebalo uopće biti moguće isticati u odnosu na djelovanje elektroničkog agenta bez obzira jesu li nastali u fazi programiranja elektroničkog agenta, odnosno prije njegova puštanja u rad ili nakon toga.

\section{ELECTRONIC AGENT}

Summary: The present paper provides an overview of the regulation concerning the electronic agent as a pure form of electronic communication for the formation of contracts by electronic means. Due to the nonexistence of regulation on the electronic agent in Europe, in Bosnia and Herzegovina and Croatioa, the author provides an overview of the regulation of the USA as a paradigmatic source of law. The difference in the understanding of the regulations in the USA and continental law is analyzed with respect to the manifestation of intent, i.e. the difference in the expression of will and manifestation of intent and their impact on contract formation via an electronic agent. Consideration is also given to the existence of intent and the way intent to conclude a contract is expressed via an electronic agent as well as the need for an objective interpretation of intent, i.e. the manifestation of intent expressed by an electronic agent and this for such person in whose name and for whose account the legal transaction is being performed. The regulations of this area are also considered within the scope of the national Law of Obligations. A minimal change of regulatory framework is suggested in order to ensure legal certainty in the use of the electronic agent in practice.

Key words: Electronic agent, concluding of contractr, expression of intention for concluding a contract, manifestation of intention, The Uniform Electronic Transactions Act, The Uniform Computer Information Transactions Act, Electronic Signatures in Global and National Commerce Act of the USA.

\footnotetext{
${ }^{129}$ Vidjeti članak 60. ZOO-a 1978. - prijetnja.

${ }^{130}$ Vidjeti članak 61. ZOO-a 1978. - bitna zabluda.

${ }^{131}$ Vidjeti članak 65. ZOO-a 1978. - prijevara.

132 Vidjeti članak 66. st. 1. ZOO-a 1978. - prividni ugovor.

${ }^{133}$ Vidjeti detaljno Komentar Zakona o obligacionim odnosima, I knjiga, drugo izdanje, Blagojević, B. (ur) i Krulj,

V. (ur), Savremena administracija, Beograd, 1983., str. 247-250.
} 